\title{
Development and Application of a RT-NestPCR Assay for Differential Detection of C-Strain and Wild-Type Viruses of Classical Swine Fever Virus
}

\author{
Haiguang Wang ${ }^{1}$, Yibao Ning ${ }^{1}$, Cong Ying ${ }^{1,2}$, Can Liu ${ }^{1}$, Ruirui Wei ${ }^{1,3} \&$ Wenzhi Gong ${ }^{1}$ \\ ${ }^{1}$ Department of Inspection Technology Research \& National Classical Swine Fever Reference Laboratory, China \\ Institute of Veterinary Drug Control, Beijing, P. R. China \\ ${ }^{2}$ College of Veterinary Medicine, Huazhong Agricultural University, Wuhan, P. R. China \\ ${ }^{3}$ College of Animal Science and Technology, Qingdao Agricultural University, Qingdao, P. R. China \\ Correspondence: Yibao Ning, Department of Inspection Technology Research, China Institute of Veterinary Drug \\ Control, Beijing, 100081, P. R. China. Tel: 86-6210-3674. E-mail: ningyibao@ivdc.gov.cn
}

Received: January 17, 2013 Accepted: March 25, 2013 Online Published: April 7, 2013

doi:10.5539/sar.v2n3p27

URL: http://dx.doi.org/10.5539/sar.v2n3p27

\begin{abstract}
Due to the urgent need of differentiation of infected from vaccinated animals in control and eradication of classical swine fever (CSF) and the shortcomings of current differential diagnostic tools, this study is aiming to establish a RT-nestPCR assay for differential detection of wild-type viruses and lapinized Chinese vaccine strain (C-strain) of classical swine fever virus (CSFV) of high sensitivity. Two pairs of CSFV-specific primers were designed in the conservative regions of NS5B (a non-structural protein encoded by the CSFV genome, which performs the RNA dependent RNA polymerase activity) and 3' un-translated regions (3'-UTR) to encompass the T-rich insertion uniquely existing in the 3'-UTR of C-strain genome. Thus the amplification fragment of C-strain is longer than that of the wild-type viruses for it contains the T-rich insertion region. Two pairs of primers were used in combination and the wild-type viruses and C-strain of CSFV could be detected and accurately distinguished with a high sensitivity through super fine resolution (SFR) argarose gel electrophoresis that displays the different lengths of the amplicons. The detection limit of the C-strain and Shimen strain were respectively $4.5 \times 10^{-2} \mathrm{pg}$ and $3.2 \times 10^{-2} \mathrm{pg}$ of viral RNA. The results of the specificity test showed that this method can detect different strains of CSFV without amplifying other non-CSFV pathogens. The results of the detection of 400 clinical samples indicated that 16 samples were CSFV positive in total; in which 4 samples were C-Strain positive and 12 were wild-type CSFV positive. The total CSFV positive rate was $4 \%$. The detection results of the 14 batches of C-Strain vaccines showed that all samples displayed bands of C-Strain amplicons in the SFR argarose gel electrophoresis and all vaccines were free of wild-type virus contamination. In conclusion, the RT-nestPCR assay established in the present study could supply a sensitive and specific test method for distinguishing wild-type CSFV infected animals from those vaccinated with C-strain vaccines in the field.
\end{abstract}

Keywords: RT-nestPCR, differential detection, C-strain, wild-type virus, classical swine fever virus

\section{Introduction}

Classical swine fever (CSF) is a highly contagious multisystem, hemorrhagic swine disease caused by classical swine fever virus (CSFV). Clinical syndromes of various stages and severity from acute death to silent infection can be observed (van Oirschot, 2003). Classical swine fever virus (CSFV) is currently classified as a member of the genus Pestivirus in the family Flaviviridae, of a close phylogenetic relationship with bovine viral diarrhea virus species 1 (BVDV-1), bovine viral diarrhea virus species 2 (BVDV-2), the ovine border disease virus (BDV) (Fauquet \& Mayo, 2001; Mayo \& Haenni, 2006). CSFV is an enveloped virus with a single-stranded positive sense RNA genome containing only one open reading frame (ORF) which encodes a polyprotein of about 4000-amino-acid. The viral genome is of $12.5 \mathrm{~kb}$ in size with one highly conserved un-translated region (UTR) at 5 'and 3 'end respectively. The polyprotein encoded by the genome is further processed into 12 proteins or polypeptides by viral and cellular proteases during or after the translation(Greiser-Wilke et al., 2006). Currently, CSF is the major impediment in the international trade of pork related products. Extremely serious economic loss can be caused due to the outbreak of CSF. For instance, in Netherland, over 10 million pigs were slaughtered 
during 1997 and 1998 due to the catastrophic epidemic of CSF (Moennig, 2000). In the present, the mostly used detection methods of CSF pathogens are conventional RT-PCR, antigen capture ELISA, virus isolation (VI), immunofluorescence assay (FA), indirect-immunofluorescence assay (IFA) and immunoperoxidase assay (IPA) (Depner et al., 1995; Dewulf et al., 2004; Haegeman et al., 2006; Handel et al., 2004) etc. Nevertheless, these methods are either comparatively less sensitive or incapable of differential detection of pigs vaccinated with CSFV vaccines or infected with wild-type viruses. Currently, the major procedure for control and prevention of CSF in mainland China is through massive mandatory vaccination of C-Strain vaccine (Qiu, 2006). However, the vaccine viruses can persist in pigs for a relatively long period of time after vaccination (Lorena et al., 2001). Therefore, the major problem faced by the breeding swine farms in the process of CSF eradication is the differentiation of pigs vaccinated with CSFV vaccines or infected with wild-type viruses. Furthermore, The clinical picture of CSFV infection is highly variable and influenced by various viral and host factors, such as virulence of the virus, age of the pig, and time of the infection (pre or post-natal) (Liu et al., 2007). Consequently, the establishment of a rapid and highly sensitive laboratory diagnostic method which is also capable of differential detection of CSFV C-strain vaccine and wild-type viruses is essential for the control, prevention and eradication of CSF in mainland China.

Detection of CSFV, BVDV and BDV using conventional RT-PCR can be achieved through designing specific primers (Canal et al., 1996). The differential detection of CSFV vaccine viruses, wild-type viruses and certain other pestiviruses can also be archived by conducting restriction endonuclease cleavage of PCR amplicons after the RT-PCR amplification (Vilcek \& Belak, 1998; Vilcek et al., 1994). A multiplex nested RT-PCR (Li et al., 2007) and a multiplex real-time RT-PCR (Zhao et al., 2008) for differential diagnostic of wild-type viruses and the C-strain vaccine were also described. Obviously, detection of the viral nucleic acid by PCR satisfies the need of high speed and high sensitivity, and therefore it has been widely used for clinical diagnostic purposes (Liu et al., 2007). By conducting a second round nested PCR, the sensitivity of the conventional PCR assay can be greatly enhanced, compared to virus isolation, CSFV can be detected 2.8 days earlier and during a longer period in whole blood samples of the infected pigs (Dewulf et al., 2004).

The differential detection of CSFV vaccine and wild-type viruses is of great significance for clinical detection of CSFV, eradication of CSF in breeding swine farms and purity test of CSFV vaccines (Sun et al., 2011a; Sun et al., 2011b; Sun et al., 2010a; Sun et al., 2010b; Tu et al., 2001; Zhu et al., 2009). Taking into account the limited sensitivity of conventional RT-PCR and the restriction endonuclease cleavage of PCR amplicons after the RT-PCR reaction is laborious, time consuming and easy to get contaminated, therefore, it is essential to establish a differential diagnostic technique with high sensitivity (Dewulf et al., 2004; Haegeman et al., 2006; Hoffmann et al., 2009; Vilcek \& Belak, 1998).

The CSFV C-strain vaccines are currently the most widely used vaccines in the world for the immunization of pigs against CSFV (Qiu, 2006). Through sequence analysis, a significant T-rich insertion of typically 12 nucleotides (nt) in length (CTTTTTTCTTTT) was recognized in the 3'-UTR of the C-strain vaccine viral genomes, and this T-rich insertion is absent in the CSFV wild-type viruses viral genomes (Moormann et al., 1996; Nie et al., 2001; Wong et al., 2001; Wu et al., 2001). Clearly, the typically 12nt T-rich insertion is a distinctive marker in discrimination of CSFV C-strain vaccine and wild-type viruses.

In this study, a simple, rapid RT-nestPCR assay was developed by designing specific outer and inner primer pairs used in combination outside the T-rich insertion region of C-strain vaccine viral genome, and the usefulness of this method in routine clinical diagnosis of animals infected with CSFV was determined. The assay was not only able to detect CSFV with high sensitivity, but also able to distinguish wild-type virus infections from vaccine strain vaccinations. It can also provide a convenient method for detection of CSFV wild-type viruses' contaminations in the CSFV vaccines.

\section{Materials and Methods}

\subsection{Viruses, Vaccines and Clinical Samples}

Viruses, vaccine strain and mycoplasma strains (Supplied by China Veterinary Culture Collection Center in China Institute of Veterinary Drug Control) used in this study are listed in Table 1. 400 tonsil tissue samples in total were collected alive from clinical healthy pigs from different breeding swine farms in Henan, Hebei and Shandong Province in Northern China. The tissues were homogenized using the MagNA Lyser bead beater (Roche, Switzerland) according to the existing protocol (Ophuis et al., 2006). The homogenate was stored in -70 ${ }^{\circ} \mathrm{C}$ before use. A total of 14 batches of C-strain vaccines from different manufacturers were used in this study. All the vaccines were dissolved in $3 \mathrm{~mL}$ vaccine dilution and stored in $-20{ }^{\circ} \mathrm{C}$ before use. 
Table 1. Viruses and vaccine strain used in this study

\begin{tabular}{llll}
\hline Virus & Isolates and Strains & Subgenotypes & GenBank Locus \\
\hline HCLV(vaccine strain) & C-Strain & 1.1 & AF091507.1 \\
& Shimen & 1.1 & AY775178.2 \\
CSFV (wild-type strains) & HeB & 2.1 & EF421708 \\
& SX & 2.1 & EF421699 \\
& BJ & 2.2 & EF421669.1 \\
BVDV & NADL & $/$ & M31182.1 \\
& Oregon C24 & $/$ & AF091605.1 \\
PRRSV & GD & $/$ & EU825724.1 \\
& JXA1 & $/$ & EF112445.1 \\
PPV & NADL-2 & $/$ & L23427.1 \\
& Mu-1 & $/$ & $/$ \\
PrV & MinA-Strain & $/$ & $/$ \\
PEDV & Su-Strain & $/$ & AF353511.1 \\
TEGV & CV777 & $/$ & $/$ \\
PCV-2 & STC3 & $/$ & Z12107.1 \\
PRV & SH & $/$ & AY765211.1 \\
M.bovis & OSU & $/$ & X58556.1 \\
Ora & $/$ & $/$ & X58555.1 \\
Mho & $/$ & $/$ & $/$
\end{tabular}

$\mathrm{HCLV}=$ attenuated lapinized chinese strain of classical swine fever virus, CSFV=classical swine fever virus, $\mathrm{BVDV}=$ bovine viral diarrhea virus, $\mathrm{PRRSV}=$ porcine reproductive and respiratory syndrome virus, $\mathrm{PPV}=$ porcine parvovirus, $\operatorname{PrV}=$ pseudorabies virus, $\mathrm{PEDV}=$ porcine epidemic diarrhea virus, $\mathrm{TEGV=transmissible}$ gastroenteritis virus of swine, PCV-2=porcine circovirus II, PRV=porcine rotavirus, M.bovis= Mycoplasma bovis, Ora $=$ mycoplasma orale, $\mathrm{Mho}=$ mycoplasma hyorhinis.

\subsection{Primer Design}

The whole genome sequences of 57 CSFV strains and isolates, 18 BVDV strains and isolates, 7 BDV strains and isolates retrieved from GenBank were aligned by MEGA 5.05 software using Clustal W algorithm. The T-rich insertion was found exclusively in the 3'-UTR of C-strain vaccine viral genome as expected (Figure 1, partial sequence alignment of CSFV viral genomes is shown, sequence alignments of BVDV viral genomes and BDV viral genomes are not shown). Two pairs of primers were designed in the conservative regions of NS5B and 3'-UTR regions based on the sequence analysis to encompass the T-rich insertion region so that the PCR and nested PCR amplicons of the $\mathrm{C}$-strain vaccine are longer than that of wild-type viruses for the T-rich insertion regions are absent in the $3^{\prime}$-UTR of the wild-type viruses viral genomes (Figure 2).

The two pairs of primers are as follows:

CSFV-Out-2-F: 5'-CAACTGGCTVGTYAAYGC-3'

CSFV-Out-2-R: 5'-AATGAGTGTAGTGTGGTAAC-3'

CSFV-In-2-F: 5'-ATGATGATGVCSCTKATAG-3'

CSFV-In-2-R: 5'-GTGTGGTAACWTGAGGTAG-3'

$(\mathrm{V}=\mathrm{A}$ or $\mathrm{G} ; \mathrm{Y}=\mathrm{C}$ or $\mathrm{T} ; \mathrm{S}=\mathrm{C}$ or $\mathrm{G} ; \mathrm{K}=\mathrm{T}$ or $\mathrm{G} ; \mathrm{W}=\mathrm{A}$ or $\mathrm{T})$

The sizes of the PCR products of the outer primer pairs (CSFV-Out-2-F, CSFV-Out-2-R) are 397-409 bp and 384-386 bp in CSFV vaccines and wild-type viruses respectively. The sizes of the PCR products of the inner 
primer pairs (CSFV-In-2-F, CSFV-In-2-R) are 191-203 bp and 178-180 bp in CSFV vaccines and wild-type viruses respectively. The outer primer pairs and the inner primer pairs were used in combination to conduct a RT-nestPCR assay to enhance sensitivity.

\begin{tabular}{|c|c|c|c|c|c|c|c|c|c|c|c|c|c|c|c|c|c|c|c|c|c|c|c|c|c|c|c|c|c|c|c|c|c|c|c|c|c|c|}
\hline 1. C & A & $\mathrm{T}$ & A & A & C & A & C & $\mathrm{T}$ & A & A & $\mathrm{T}$ & $\mathrm{T}$ & $\mathrm{T}$ & $\mathrm{T}$ & C & $\mathrm{T}$ & $\mathrm{T}$ & $\mathrm{T}$ & $\mathrm{T}$ & $\mathrm{T}$ & $T$ & T & C & $T$ & $\mathrm{~T}$ & $\mathrm{~T}$ & $\mathrm{~T}$ & $\mathrm{~T}$ & $\mathrm{~T}$ & A & $\mathrm{T}$ & $\mathrm{T}$ & $\mathrm{T}$ & A & T & T & $\bar{T}$ & 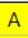 \\
\hline$\nabla 2 . C$ & A & $T$ & A & A & 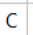 & A & C & $T$ & A & A & $T$ & T & T & $T$ & C & - & $T$ & $T$ & T & $T$ & $T$ & $T$ & $\mathrm{C}$ & $T$ & T & $\mathrm{T}$ & $\mathrm{T}$ & $\mathrm{T}$ & $\mathrm{T}$ & A & $T$ & T & $T$ & A & $\mathrm{T}$ & $T$ & $\mathrm{~T}$ & A \\
\hline$\nabla 3 . c$ & & & & A & C & & C & $T$ & 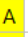 & A & $T$ & T & $\mathrm{T}$ & $T$ & C & - & $T$ & $T$ & 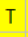 & $T$ & $T$ & $\mathrm{~T}$ & C & $T$ & T & $T$ & $\mathrm{~T}$ & $\mathrm{~T}$ & $\mathrm{~T}$ & A & $T$ & T & $T$ & A & $\mathrm{T}$ & $\mathrm{T}$ & $T$ & A \\
\hline$\nabla 4 . c$ & & & & A & C & & c & 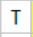 & & C & $T$ & Т & $T$ & $T$ & C & - & $\mathrm{T}$ & $\mathrm{T}$ & $\mathrm{T}$ & $T$ & $T$ & $T$ & & $T$ & $T$ & $\mathrm{~T}$ & $\mathrm{~T}$ & $\mathrm{~T}$ & $\mathrm{~T}$ & A & $T$ & T & $T$ & A & $T$ & $\mathrm{~T}$ & $\mathrm{~T}$ & $A$ \\
\hline$\nabla 5$. & A & T & 1 & A & C & A & C & $T$ & A & A & $T$ & T & T & $T$ & C & - & $\mathrm{T}$ & $T$ & T & $T$ & $T$ & $T$ & C & $T$ & T & $\mathrm{T}$ & $\mathrm{T}$ & $\mathrm{T}$ & $\mathrm{T}$ & A & $T$ & $T$ & $T$ & A & $\mathrm{T}$ & $T$ & $\mathrm{~T}$ & A \\
\hline$\nabla 6 . C$ & A & & A & A & C & A & C & $T$ & A & A & $T$ & $T$ & T & $T$ & $C$ & - & $T$ & $T$ & $\mathrm{~T}$ & $\mathrm{~T}$ & $T$ & $T$ & $T$ & $T$ & $T$ & $T$ & $\mathrm{~T}$ & $T$ & T & A & $T$ & $\mathrm{~T}$ & $T$ & A & $\mathrm{T}$ & T & $T$ & A \\
\hline$\nabla 7.0$ & A & T & 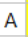 & A & C & & C & $T$ & a & A & C & T & $T$ & A & $T$ & - & - & - & - & - & - & - & - & - & - & - & - & - & T & A & $T$ & $\mathrm{~T}$ & $T$ & A & $\mathrm{T}$ & $T$ & $\mathrm{~T}$ & A \\
\hline$\checkmark 8 . C$ & A & $\mathrm{T}$ & A & A & C & 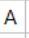 & C & $T$ & A & A & $T$ & T & T & $T$ & $T$ & - & - & - & - & - & - & - & - & - & - & - & - & - & $T$ & A & $T$ & $\mathrm{~T}$ & $T$ & A & $\mathrm{T}$ & $T$ & $\mathrm{~T}$ & A \\
\hline$\nabla 9$. & A & & 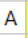 & A & C & & $T$ & $\mathrm{~T}$ & 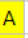 & A & C & T & $T$ & A & $T$ & - & - & - & - & - & - & - & - & - & - & - & - & - & $\mathrm{T}$ & A & $T$ & $\mathrm{~T}$ & $\mathrm{~T}$ & A & $\mathrm{T}$ & $\mathrm{T}$ & $\mathrm{T}$ & A \\
\hline$\nabla 10$. & A & $\mathrm{T}$ & 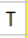 & A & C & & C & $\mathrm{T}$ & A & A & C & T & $T$ & A & $T$ & - & - & - & - & - & - & - & - & - & - & - & - & - & $T$ & A & $T$ & $T$ & $T$ & A & $T$ & $T$ & $T$ & A \\
\hline$\checkmark 11$. & A & $\mathrm{T}$ & A & A & C & A & $\mathrm{T}$ & C & A & A & C & $T$ & $T$ & A & $T$ & - & - & - & - & - & - & - & - & - & - & - & - & - & T & A & A & $\mathrm{T}$ & $T$ & A & C & $\mathrm{T}$ & $\mathrm{T}$ & A \\
\hline$\checkmark 12$. & 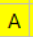 & 1 & A & A & C & & T & $\mathrm{T}$ & 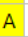 & A & $T$ & 1 & $T$ & A & $T$ & - & - & - & - & - & - & - & - & - & - & - & - & - & 1 & A & A & $\mathrm{T}$ & $T$ & A & $\mathrm{T}$ & C & $\mathrm{T}$ & A \\
\hline$\checkmark 13$. & A & T & 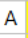 & A & C & & C & $T$ & A & A & $T$ & $\mathrm{~T}$ & $T$ & $T$ & $T$ & - & - & - & - & - & - & - & -6 & - & - & - & - & - & $T$ & A & $\mathrm{T}$ & $T$ & $T$ & A & $T$ & $T$ & $\mathrm{~T}$ & A \\
\hline$\nabla 14$. & A & $\mathrm{T}$ & A & A & C & A & C & $T$ & A & A & $T$ & $T$ & $T$ & $T$ & $T$ & - & - & - & - & - & - & - & - & - & - & - & - & - & $T$ & A & $T$ & $\mathrm{~T}$ & $T$ & A & $T$ & $T$ & $\mathrm{~T}$ & A \\
\hline$\checkmark 15$. & A & 1 & A & A & $c$ & & $\mathrm{~T}$ & C & A & A & C & T & $T$ & A & $T$ & - & - & - & - & - & - & - & - & - & - & - & - & - & $\mathrm{T}$ & A & A & C & $T$ & A & $\mathrm{T}$ & T & $\mathrm{T}$ & A \\
\hline$\nabla 16.0$ & A & $\mathrm{T}$ & A & A & C & A & $T$ & $\mathrm{~T}$ & 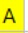 & A & C & $\mathrm{T}$ & T & A & $T$ & - & - & - & - & - & - & - & - & - & - & - & - & - & $\mathrm{T}$ & A & A & $\mathrm{T}$ & $T$ & A & $\mathrm{T}$ & $\mathrm{T}$ & $\mathrm{T}$ & A \\
\hline v17. & A & $\mathrm{T}$ & A & A & C & A & T & $T$ & A & A & C & T & $T$ & A & $T$ & - & - & - & - & - & - & - & - & - & - & - & - & - & $\mathrm{T}$ & A & A & $\mathrm{T}$ & $T$ & A & $\mathrm{T}$ & $\mathrm{T}$ & $T$ & A \\
\hline$\nabla 18$. & A & 1 & 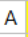 & A & $c$ & & T & $\mathrm{T}$ & 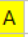 & A & C & $\mathrm{T}$ & $T$ & A & $T$ & - & - & 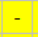 & - & - & - & - & - & - & - & - & - & - & T & A & A & $\mathrm{T}$ & $T$ & 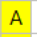 & $\mathrm{T}$ & T & $T$ & A \\
\hline$\nabla 19$. & A & T & A & A & C & A & $T$ & $T$ & . & A & C & $\mathrm{T}$ & $T$ & A & $T$ & - & - & - & - & - & - & - & - & - & - & - & - & - & $T$ & A & A & $T$ & $T$ & A & $T$ & $T$ & $T$ & A \\
\hline$\nabla 20$. & A & $\mathrm{T}$ & A & A & C & 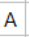 & C & $T$ & A & A & $T$ & $\mathrm{~T}$ & T & $\mathrm{T}$ & $T$ & - & - & - & - & - & - & - & - & - & - & - & - & - & T & A & $\mathrm{T}$ & $\mathrm{T}$ & $\mathrm{T}$ & A & $\mathrm{T}$ & $T$ & $T$ & A \\
\hline$\nabla 21$. & A & T & 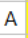 & A & $\mathrm{T}$ & & G & $T$ & A & A & C & $\mathrm{T}$ & $T$ & A & $T$ & - & - & - & - & - & - & - & - & - & - & - & - & - & $T$ & A & $T$ & $T$ & $\mathrm{~T}$ & A & $T$ & G & $T$ & A \\
\hline$\nabla 22$. & 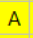 & $T$ & A & A & C & A & C & $T$ & . & A & $\mathrm{T}$ & $T$ & $T$ & $T$ & $T$ & - & - & - & - & - & - & - & - & - & - & - & - & - & $T$ & A & $T$ & $\mathrm{~T}$ & $T$ & A & $\mathrm{T}$ & $\mathrm{T}$ & $T$ & A \\
\hline$\nabla 23$. & A & $\mathrm{T}$ & A & A & C & 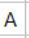 & C & $T$ & A & A & $\mathrm{T}$ & $\mathrm{T}$ & $T$ & A & $T$ & - & - & - & - & - & - & - & - & - & - & - & - & - & - & A & T & $\mathrm{T}$ & $T$ & A & $\mathrm{T}$ & $\mathrm{T}$ & $T$ & A \\
\hline$\nabla 24$. & A & T & A & A & C & & C & $\mathrm{T}$ & & A & C & 1 & $T$ & A & $T$ & - & - & - & - & - & - & - & - & - & - & - & - & - & $T$ & A & $T$ & $\mathrm{~T}$ & $\mathrm{~T}$ & A & A & G & $T$ & 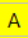 \\
\hline$\nabla 25$. & A & $T$ & A & A & C & A & C & $T$ & A & A & C & $T$ & $T$ & A & $T$ & - & - & - & - & - & - & - & - & - & - & - & - & - & $T$ & A & $T$ & $\mathrm{~T}$ & $T$ & A & $T$ & $T$ & $T$ & A \\
\hline$\checkmark 26$. CSFV & A & T & A & A & C & . & C & $T$ & A & A & C & $\mathrm{T}$ & T & A & $T$ & - & - & - & - & - & - & - & - & - & - & - & - & - & $T$ & A & $T$ & $T$ & $T$ & A & $T$ & $T$ & $T$ & A \\
\hline$\nabla 27$. & $\Delta$ & 1 & A & A & C & & ( & $T$ & & A & C & & $\mathrm{T}$ & A & $T$ & - & - & - & - & - & - & - & - & - & - & - & - & - & $T$ & A & C & $\mathrm{T}$ & $T$ & A & $\mathrm{T}$ & $\mathrm{T}$ & $T$ & A \\
\hline$\nabla 28$. & A & $\mathrm{T}$ & A & A & C & A & $T$ & $T$ & A & A & C & $T$ & $T$ & A & $T$ & - & - & - & - & - & - & - & - & - & - & - & - & - & $T$ & A & A & $\mathrm{T}$ & $T$ & A & $\mathrm{T}$ & $T$ & $T$ & 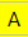 \\
\hline$\checkmark 29$. CSFV & A & $T$ & A & A & C & A & C & $T$ & A & A & $T$ & $\mathrm{~T}$ & T & $T$ & $T$ & - & - & - & - & - & - & - & - & - & - & - & - & - & T & A & $T$ & $\mathrm{~T}$ & $T$ & A & $T$ & $T$ & $T$ & A \\
\hline$\nabla 30$. & 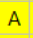 & 1 & A & A & C & & $T$ & $T$ & A & A & C & 1 & $T$ & A & $\mathrm{T}$ & - & - & - & - & - & - & - & - & - & - & - & - & - & $T$ & A & $T$ & $\mathrm{~T}$ & $T$ & A & $\mathrm{T}$ & G & $T$ & A \\
\hline$\nabla 31$. & A & $\mathrm{T}$ & A & A & C & A & C & $T$ & A & A & $T$ & $T$ & $T$ & $T$ & $T$ & - & - & - & - & - & - & - & - & - & - & - & - & - & - & A & $T$ & $T$ & $T$ & A & $T$ & $T$ & $T$ & A \\
\hline$\nabla 32$. & A & $\mathrm{T}$ & A & A & C & A & C & $\mathrm{T}$ & A & G & C & C & T & A & $T$ & - & - & - & - & - & - & - & - & - & - & - & - & - & A & G & $\mathrm{T}$ & $\mathrm{T}$ & $T$ & A & C & A & $T$ & A \\
\hline - $33 . \mathrm{CSF}$ & A & $\mathrm{T}$ & A & A & C & A & $\mathrm{C}$ & $\mathrm{T}$ & A & A & $\mathrm{T}$ & T & T & $\mathrm{T}$ & $T$ & - & - & - & - & - & - & - & - & - & - & - & - & - & - & A & $T$ & $\mathrm{~T}$ & $T$ & A & $\mathrm{T}$ & $\mathrm{T}$ & $T$ & A \\
\hline
\end{tabular}

Figure 1. Sequence alignment of different strains and isolates of classical swine fever viruses viral genomes. The T-rich insertions were circumscribed by the red lines. Sequence 1-6: genomes of CSFV C-strain vaccines.

Sequence 7-33: genomes of CSFV wild-type viruses

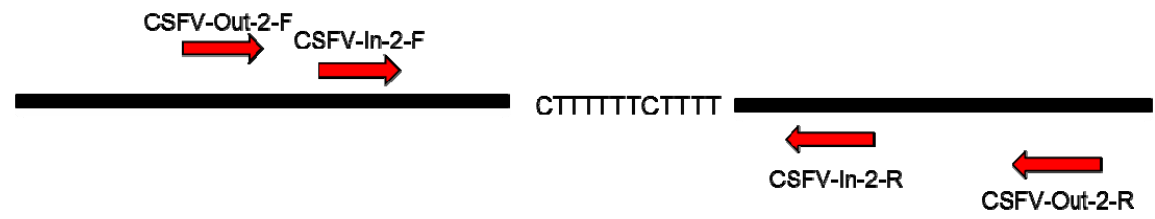

Figure 2. The designing region of the primer pairs used in the RT-nestPCR assay

\subsection{Development of RT-NestPCR Assay}

\subsubsection{Isolation of Viral RNA and Reverse Transcription, Isolation of Mycoplasma DNA}

Viral RNA was extracted from $200 \mu \mathrm{L}$ of cell culture supernatants, tissue homogenates or diluted vaccines with the RNeasy Plus Mini Kit (Qiagen, Germany), according to manufacturer's manual (revised), Reverse transcription was performed in a final volume of $10 \mu \mathrm{L}$ containing $5 \mu \mathrm{L}$ of RNA, $2 \mu \mathrm{L}$ of $5 \times \mathrm{RT}$ Buffer (Invitrogen, USA), $1.2 \mu \mathrm{L}$ of dNTPs (10 mM each), $1 \mu \mathrm{L}$ CSFV-Out-2-R primer $(10 \mu \mathrm{M}), 60 \mathrm{U}$ of SuperScript III reverse transcriptase (Invitrogen, USA), and $0.5 \mu \mathrm{L}$ of DTT (Invitrogen, USA). The reaction mix was incubated at $55^{\circ} \mathrm{C}$ for $1 \mathrm{~h}$ and then at $70{ }^{\circ} \mathrm{C}$ for $15 \mathrm{~min}$. Mycoplasma genomic DNA was extracted using QIAamp DNA Blood Midi Kit (Qiagen, Germany) according to the manufacturer's manual. 


\subsubsection{Optimization of PCR and Nested-PCR Conditions}

The annealing temperatures of PCR and nested PCR reactions were optimized respectively by setting temperature gradients. The concentrations of different reagents in the PCR and nested PCR reaction mixes were also optimized respectively with orthogonal experimental design, including the concentrations of Hot Start Taq DNA polymerase (TaKaRa, China), dNTPs and primer pairs.

The amplified products were analyzed by electrophoresis through $4 \%(\mathrm{w} / \mathrm{v})$ super fine resolution (SFR) agarose gel (Amresco, Germany) that contained $1 \mathrm{mg} / \mathrm{ml}$ GelRed DNA gel stain (Biotium, USA) in $0.5 \times$ Tris- Borate -EDTA (TBE) solution and photographed.

\subsubsection{Sensitivity and Specificity Tests}

The viral RNA of CSFV C-strain vaccine and Shimen strain virus were extracted respectively, and the concentrations of RNA were measured on ND-1000. A 10-fold serial dilution of viral RNA using RNase-free water was executed to assess the sensitivity of the RT-nestPCR. The amplified products were analyzed by electrophoresis and photographed.

In the specificity test, viruses of different strains and isolates of CSFV, BVDV, PRRSV, PPV, PrV, PEDV, PEGV, PCV-2, PRV and common mycoplasma strains of M. bovis, Ora, Mho, normal cell culture supernatants (PK-15 cell, ST cell) were detected by the RT-nestPCR assay. The amplified products were analyzed by electrophoresis and photographed. The PCR products of expecting size were purified by using the QIAQuick gel extraction Kit (QIAGEN, Germany) through gel extraction, and the purified DNA was then cloned into pMD-18T vector (TaKaRa, China) and sequenced by Invitrogen Co. to evaluate the specificity of the assay.

2.3.4 Detection and Differentiation of CSFV C-strain Vaccine and Wild-Type Viruses in Clinical Samples and Manufactured C-Strain Vaccines by RT-NestPCR Assay

400 tonsil tissue samples in total were collected alive from clinical healthy pigs from different breeding swine farms in Henan, Hebei and Shandong province in northern China and a total of 14 batches of C-strain vaccines from different manufacturers were determined by the RT-nestPCR amplification to distinguish the C-strain vaccines from wild-type viruses in the tested samples. The amplified products were analyzed by electrophoresis and photographed. The nested PCR products of expecting size were purified by using the QIAQuick gel extraction Kit (QIAGEN, Germany) through gel extraction, and the purified DNA was cloned into pMD-18T vector and sequenced by Invitrogen Co. for further identification.

\section{Results}

\subsection{Optimization of PCR and Nested PCR Conditions}

The annealing temperatures of PCR and nested PCR reactions were optimized by setting temperature gradients (Figures 3 and 4). The concentrations of Hot Start Taq DNA polymerase (TaKaRa, China), dNTPs and primer pairs of PCR and nested PCR reactions were optimized according to the setup of the orthogonal test table $\mathrm{L}_{16}\left(4^{5}\right)$, respectively (Figures 5 and 6). The orthogonal test table was not shown.

The optimized PCR reaction was performed in a final volume of $50 \mu \mathrm{L}$ containing $5 \mu \mathrm{L}$ of $10 \times \mathrm{PCR}$ Buffer $\left(\mathrm{Mg}^{2+}\right.$ Plus); $5 \mu \mathrm{L}$ of dNTPs Mixture (each $2.5 \mathrm{mM}) ; 2 \mu \mathrm{L}$ of CSFV-Out-2-F $(10 \mu \mathrm{M}) ; 2 \mu \mathrm{L}$ of CSFV-Out-2-R (10 $\mu \mathrm{M})$; $4 \mathrm{U}$ of Hot Start Taq DNA polymerase (TaKaRa, China); $5 \mu \mathrm{L}$ of synthesized cDNA. The amplifications were performed in a TProfessional Thermocycler (Biometra, Germany) using the following steps: after an initial denaturation at $95^{\circ} \mathrm{C}$ for $1 \mathrm{~min}, 25$ cycles at $94^{\circ} \mathrm{C}$ for $30 \mathrm{~s}, 54{ }^{\circ} \mathrm{C}$ for $30 \mathrm{~s}$ and $72{ }^{\circ} \mathrm{C}$ for $30 \mathrm{~s}$, followed by a final extension at $72{ }^{\circ} \mathrm{C}$ for $10 \mathrm{~min}$.

The optimized nested PCR reaction was performed in a final volume of $50 \mu \mathrm{L}$ containing $5 \mu \mathrm{L}$ of $10 \times \mathrm{PCR}$ Buffer ( $\mathrm{Mg}^{2+}$ Plus); $4 \mu \mathrm{L}$ of dNTPs Mixture (each $\left.2.5 \mathrm{mM}\right) ; 3 \mu \mathrm{L}$ of CSFV-Out-2-F $(10 \mu \mathrm{M}) ; 3 \mu \mathrm{L}$ of CSFV-Out-2-R $(10 \mu \mathrm{M}) ; 1.5 \mathrm{U}$ of Hot Start Taq DNA polymerase (TaKaRa, China); $1 \mu \mathrm{L}$ of first round PCR Products. The amplifications were performed in the same thermo cycler using the following steps: after an initial denaturation at $95^{\circ} \mathrm{C}$ for $3 \mathrm{~min}, 35$ cycles at $94^{\circ} \mathrm{C}$ for $30 \mathrm{~s}, 56^{\circ} \mathrm{C}$ for $30 \mathrm{~s}$ and $72{ }^{\circ} \mathrm{C}$ for $20 \mathrm{~s}$, followed by a final extension at $72{ }^{\circ} \mathrm{C}$ for $10 \mathrm{~min}$. 


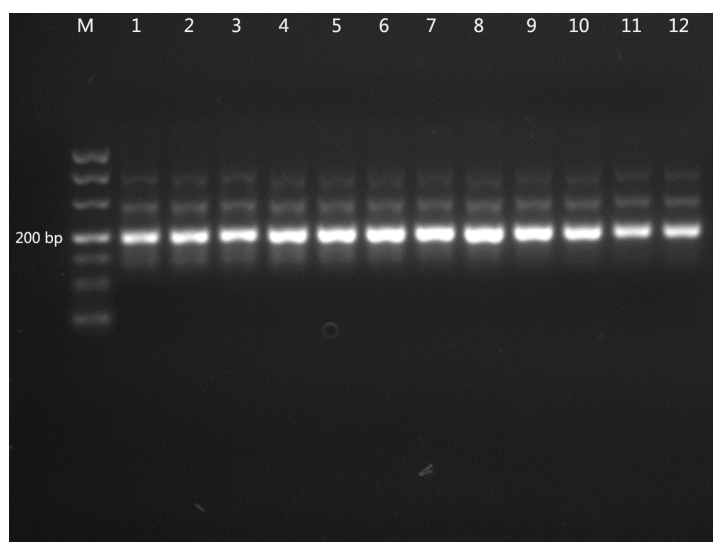

Figure 3. The optimization of annealing temperature of PCR reaction. Lane M: DL-500 DNA Marker,

Lane 1-12: temperature gradients of annealing temperature $\left(44.6{ }^{\circ} \mathrm{C}, 45^{\circ} \mathrm{C}, 46.2^{\circ} \mathrm{C}, 47.9^{\circ} \mathrm{C}, 49.9\right.$ ${ }^{\circ} \mathrm{C}, 51.9{ }^{\circ} \mathrm{C}, 54.1{ }^{\circ} \mathrm{C}, 56.1{ }^{\circ} \mathrm{C}, 58.1{ }^{\circ} \mathrm{C}, 59.8^{\circ} \mathrm{C}, 61.0$ ${ }^{\circ} \mathrm{C}, 61.4{ }^{\circ} \mathrm{C}$, respectively)

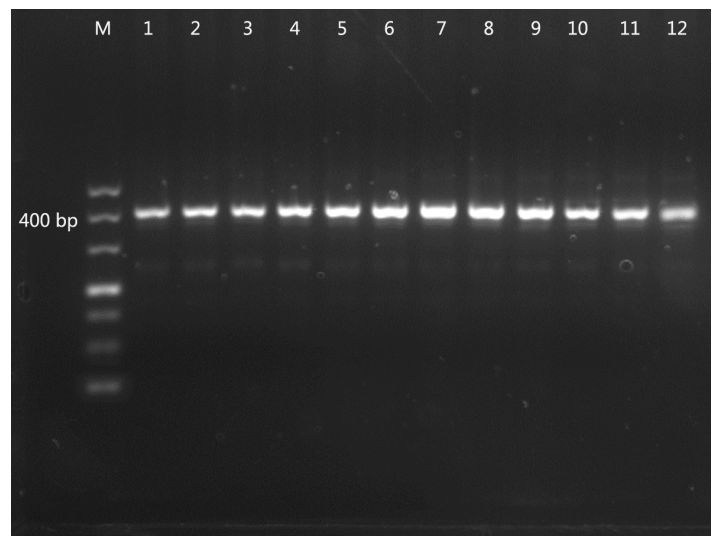

Figure 4. The optimization of annealing temperature of nested PCR reaction. Lane M: DL-500 DNA

Marker, Lane 1-12: temperature gradients of annealing temperature $\left(44.6^{\circ} \mathrm{C}, 45^{\circ} \mathrm{C}, 46.2^{\circ} \mathrm{C}, 47.9\right.$ ${ }^{\circ} \mathrm{C}, 49.9^{\circ} \mathrm{C}, 51.9^{\circ} \mathrm{C}, 54.1^{\circ} \mathrm{C}, 56.1{ }^{\circ} \mathrm{C}, 58.1{ }^{\circ} \mathrm{C}, 59.8$ ${ }^{\circ} \mathrm{C}, 61.0^{\circ} \mathrm{C}, 61.4^{\circ} \mathrm{C}$, respectively)

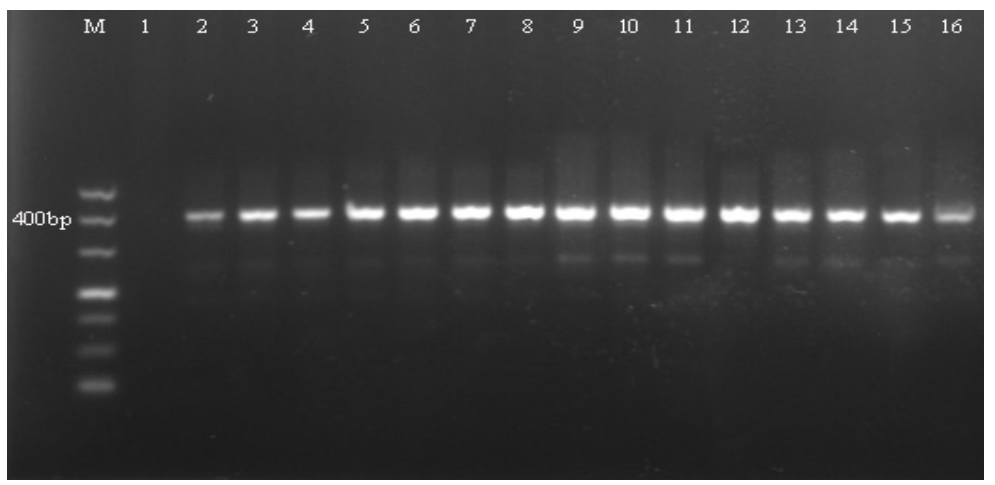

Figure 5. The optimization of concentrations of Hot Start Taq DNA polymerase, dNTPs and primer pairs in the PCR reactions. Lane M: DL-500 DNA Marker. Lane 1-16: different concentrations of Hot Start Taq DNA polymerase, dNTPs and primer pairs set up according to the orthogonal test table $\mathrm{L}_{16}\left(4^{5}\right)$, respectively

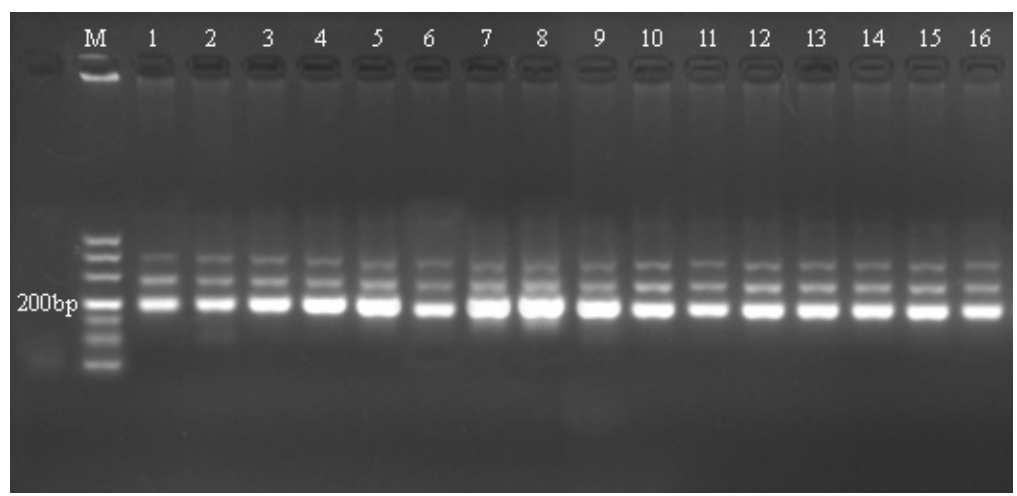

Figure 6. The optimization of concentrations of Hot Start Taq DNA polymerase, dNTPs and primer pairs in the nested PCR reactions. Lane M: DL-500 DNA Marker. Lane 1-16: different concentrations of Hot Start Taq DNA polymerase, dNTPs and primer pairs set up according to the orthogonal test table $\mathrm{L}_{16}\left(4^{5}\right)$, respectively

\subsection{Sensitivity Test}

The viral RNA of CSFV C-strain vaccine and Shimen strain virus were extracted respectively, and the concentrations of RNA were measured on ND-1000. 10-fold serial dilutions of the viral RNA $\left(10^{0}-10^{-7}\right)$ were performed and amplified by the RT-nestPCR respectively. The detection limit of RT-nestPCR assay to CSFV 
C-strain vaccine and Shimen strain virus was $4.5 \times 10^{-2} \mathrm{pg}$ and $3.2 \times 10^{-2} \mathrm{pg}$ of viral RNA respectively (Figures 7 and 8).

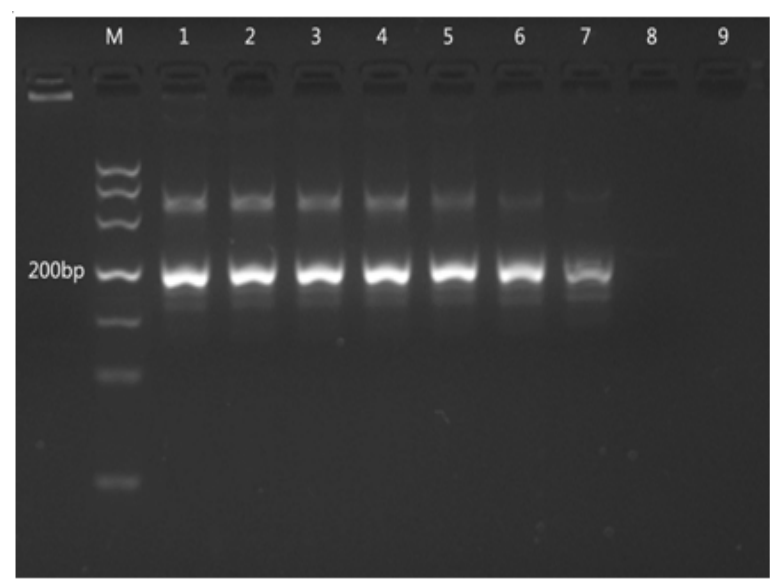

Figure 7. The detection limit of RT-nestPCR assay to CSFV C-strain vaccine. Lane M: DL-500 DNA Marker. Lane 1-8: 10-fold serial dilutions of the C-strain vaccine genomic RNA $\left(4.5 \times 10^{4}\right.$ pg- $4.5 \times 10^{-3}$ $\mathrm{pg}$, respectively). Lane 9: negative control $\left(\mathrm{dH}_{2} \mathrm{O}\right)$

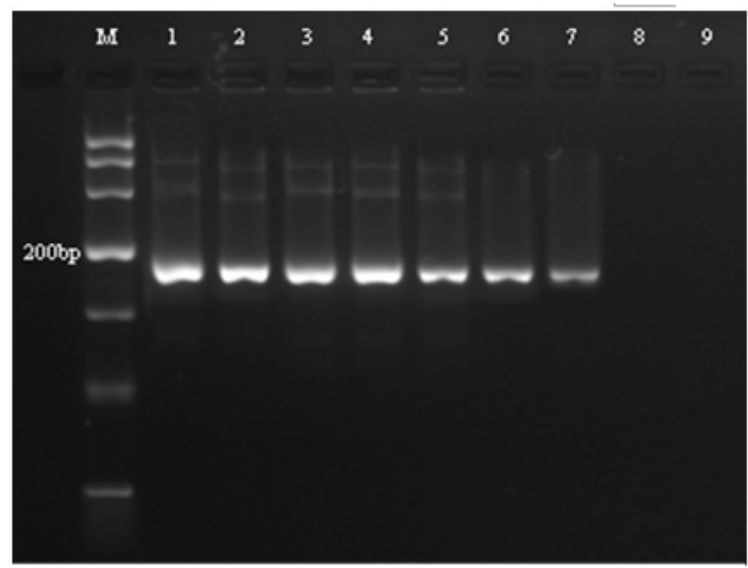

Figure 8. The detection limit of RT-nestPCR assay to CSF Shimen strain virus. Lane M: DL-500 DNA Marker. Lane 1-8: 10-fold serial dilutions of the Shimen strain virus genomic RNA $\left(3.2 \times 10^{4} \mathrm{pg}-3.2 \times 10^{-3} \mathrm{pg}\right.$, respectively). Lane 9: negative control $\left(\mathrm{dH}_{2} \mathrm{O}\right)$

\subsection{Specificity Test}

Viruses of different strains and isolates of CSFV, BVDV, PRRSV, PPV, PrV, PEDV, PEGV, PCV-2, PRV and common mycoplasma strains of M.bovis, Ora, Mho, normal cell culture supernatants (PK-15 cell, ST cell) were detected by the RT-nestPCR assay. Fragments of expecting sizes were amplified from different strains and isolates of CSFV and no amplification was observed from BVDV, PRRSV, PPV, PrV, PEDV, PEGV, PCV-2, PRV and common mycoplasma strains of M.bovis, Ora, and Mho, normal cell culture supernatant (Figure 9). The nested PCR products of C-strain vaccine could be clearly distinguished from those of the CSFV wild-type viruses in 4\% SFR agarose gels electrophoresis. The sequences of the nested PCR products of expecting size were identical to the target sequences through sequence analysis with BLAST(Altschul et al., 1990). A T-rich insertion of 16 nt was found in the 3'-UTR of the CSFV C-strain vaccine. The T-rich insertion was absent in the 3'-UTR of the CSFV wild-type viruses Shimen strain, Heb isolate, SX isolate and BJ isolate.

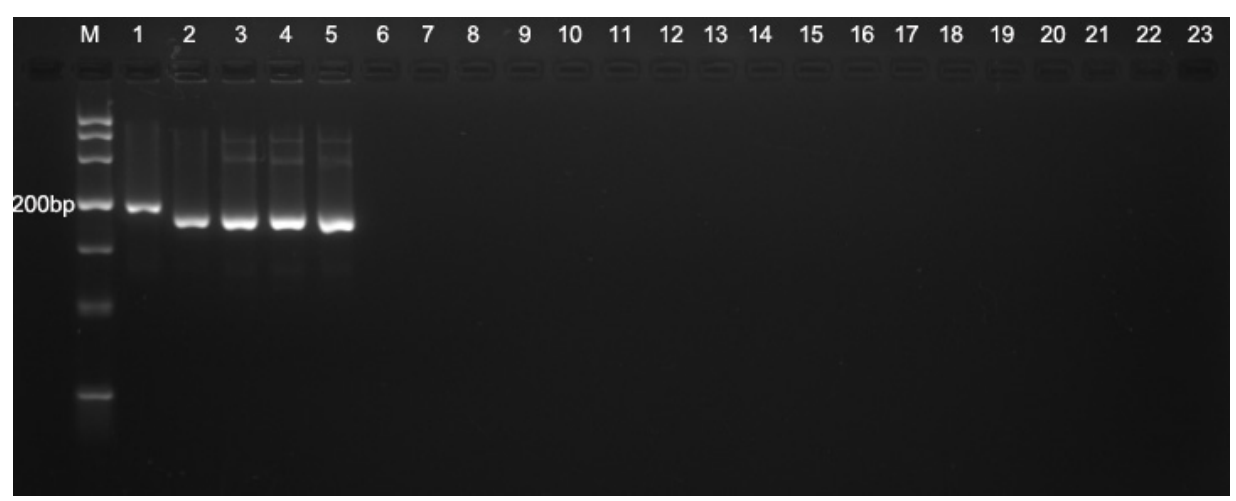

Figure 9. Specificity test of the RT-nestPCR assay. Lane M: DL-500 DNA Marker. Lane 1: CSFV C-strain vaccine. Lane 2: CSFV Shimen strain. Lane 3: CSFV Heb isolate. Lane 4: CSFV SX isolate. Lane 5: CSFV BJ isolate. Lane 6-20: BVDV NADL strain, BVDV Oregon_C24 strain, PRRSV GD strain, PRRSV JXA1 strain, PPV NADL-2 strain, PPV Mu-1 strain, PrV MinA Strain, PrV Su Strain, PEDV CV777 strain, TEGV STC3 strain, PCV-2 SH strain, PRV OSU strain, Mycoplasma M.bovis strain, Mycoplasma Ora strain, Mycoplasma

Mho strain, respectively. Lane 21: normal PK-15 cell. Lane 22: normal ST cell.

Lane 23: negative control $\left(\mathrm{dH}_{2} \mathrm{O}\right)$ 
3.4 Detection and Differentiation of CSFV C-strain Vaccine and Wild-Type Viruses in Clinical Samples and Manufactured C-Strain Vaccines by RT-NestPCR Assay

A total of 400 tonsil tissue samples and 14 batches of $C$-strain vaccines from different manufacturers were tested in this study. Among the 400 clinical samples, 12 samples were detected positive for CSFV wild-type viruses and 4 samples were detected positive for CSFV C-strain vaccines (Figures 10 and 11). All the 14 batches of C-strain vaccines were detected positive for C-strain vaccine and free of CSFV wild-type viruses' contamination (Figure 12). The sequences of the nested PCR products of expecting size supported the results of the RT-nestPCR assay through nucleotide sequence alignment by MEGA 5.05 Software (MUSCLE algorithm). The T-rich insertions were uniquely found in the 3'-UTR of the 4 CSFV C-strain vaccines and absent in the $3^{\prime}$-UTR of the 12 CSFV wild-type viruses identified by the RT-nestPCR assay (Figures 13 and 14).

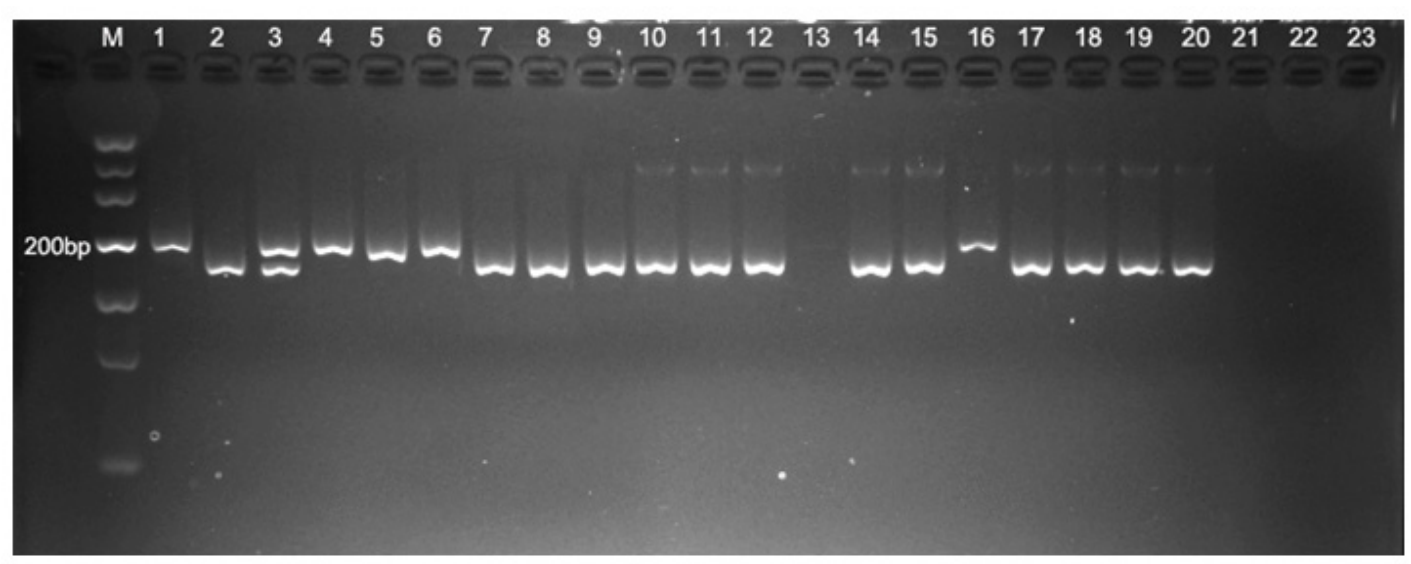

Figure 10. Agarose gel electrophoresis of parts of clinical samples detected by RT-nestPCR assay. Lane M: DL-500 DNA Marker. Lane 1-3: positive control for CSFV C-strain vaccine, wild-type virus (Shimen strain) and mixture of C-strain vaccine and wild-type virus (Shimen strain), respectively. Lane 4-22: parts of clinical samples. Lane 23: negative control $\left(\mathrm{dH}_{2} \mathrm{O}\right)$

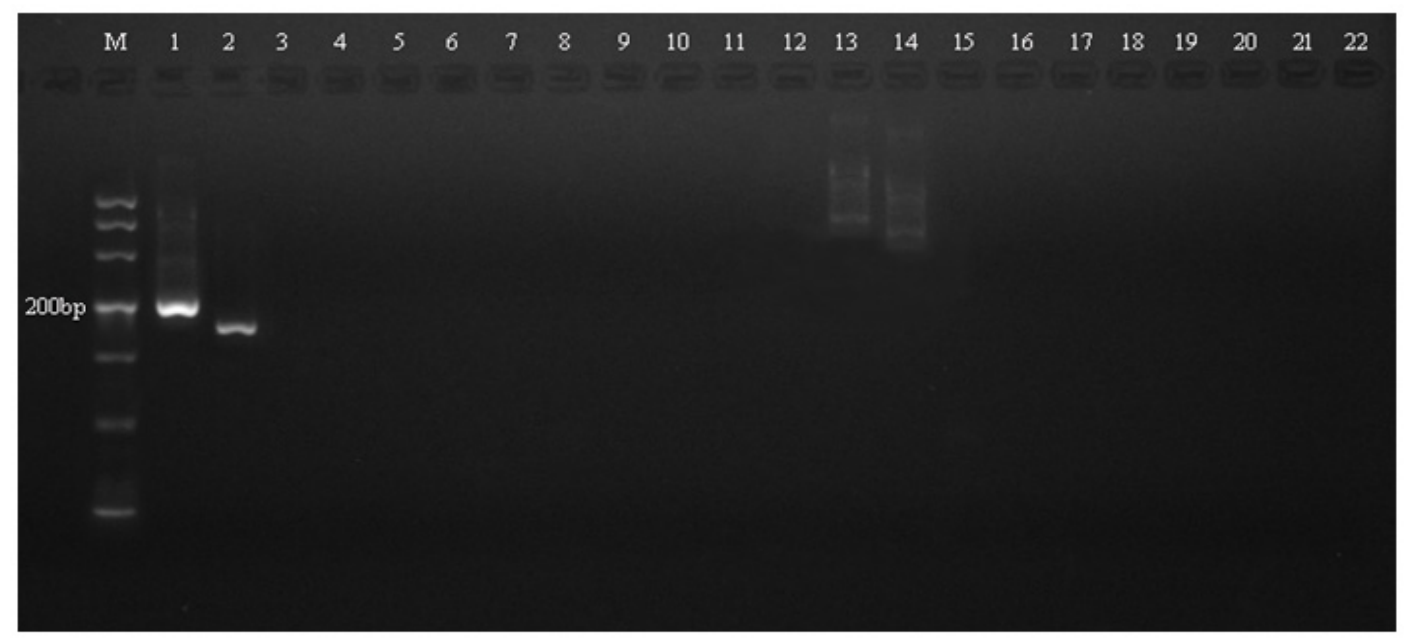

Figure 11. Agarose gel electrophoresis of parts of clinical samples detected by RT-nestPCR assay. Lane M:

DL-500 DNA Marker. Lane 1-2: positive control for CSFV C-strain vaccine and wild-type virus (Shimen strain). Lane 3-21: parts of clinical samples, Lane 22: negative control $\left(\mathrm{dH}_{2} \mathrm{O}\right)$ 


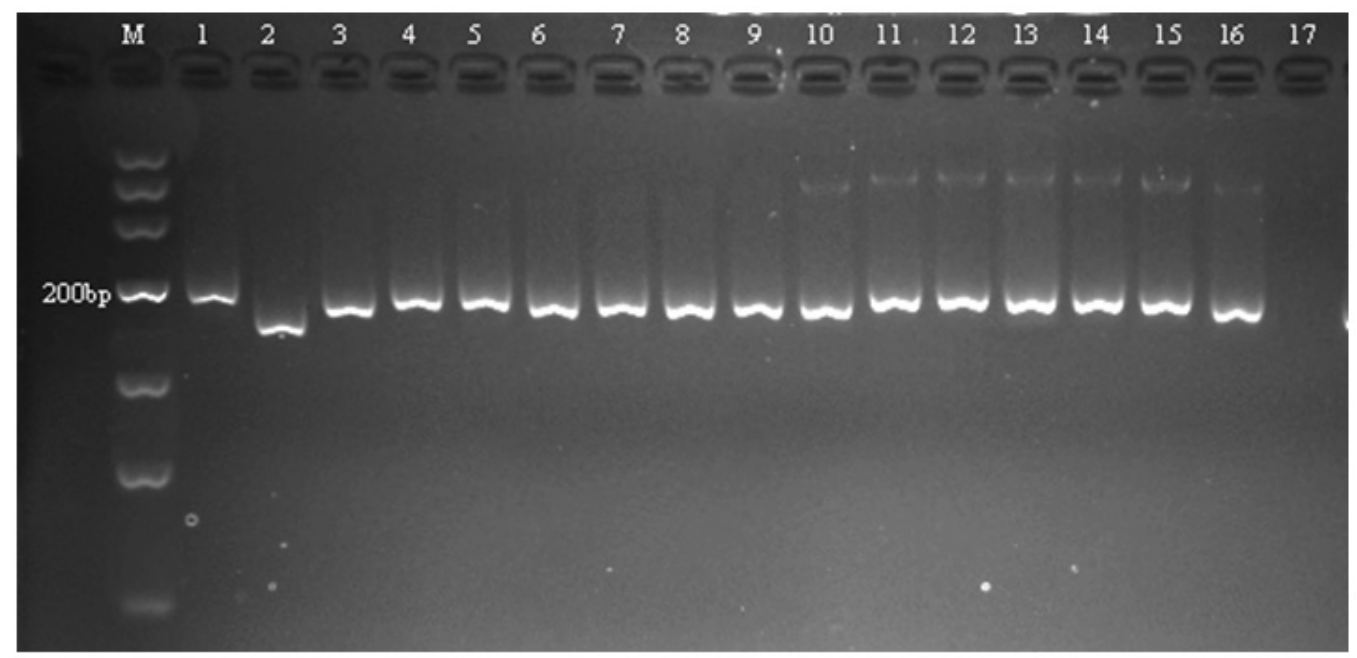

Figure 12. Agarose gel electrophoresis of 14 batches of C-strain vaccines from different manufacturers detected by RT-nestPCR assay. Lane M: DL-500 DNA Marker. Lane 1-2: positive control for CSFV C-strain vaccine and wild-type virus (Shimen strain). Lane 3-16: The $1^{\text {st }}$ to $14^{\text {th }}$ batch of $\mathrm{C}$-strain vaccine from different manufacturers, respectively. Lane 17: negative control $\left(\mathrm{dH}_{2} \mathrm{O}\right)$

\begin{tabular}{|c|c|c|c|c|c|c|c|c|c|c|c|c|c|c|c|c|c|c|c|c|c|c|c|c|c|c|c|c|c|c|c|c|c|c|c|c|c|c|c|c|c|c|c|c|c|}
\hline 1. CSFV C & A & & & & & T & & & & & & & & $\mathrm{T}$ & & & & & & & & & & & & & & & & $\mathrm{T}$ & $\mathrm{T}$ & & & T & & A & & & & & & & A & $\mathrm{T}$ & \\
\hline 2. ct/ & A & A & C & A & C & T & A $A$ & A & $\begin{array}{ll}\mathrm{T} & \mathrm{T} \\
\end{array}$ & $\mathrm{T}$ & T T & $\mathrm{T} C$ & $C \mathrm{~T}$ & $\mathrm{~T}$ & $T$ & & & & & $T$ & $\mathrm{~T}$ & $\mathrm{~T}$ & 1 & 1 & $\begin{array}{l}\mathrm{T} \\
\end{array}$ & T & T & T & T & $\begin{array}{l}- \\
-\end{array}$ & $\begin{array}{ll}- \\
-\end{array}$ & A & A & T & $\mathrm{T}$ & A & $\mathrm{T}$ & 1 & $\mathrm{~T}$ & A & G A & & A & $\mathrm{T}$ & \\
\hline 3. ct & A & A & C & A & C & T & A $A$ & A & T & $\mathrm{T}$ & T T & $c$ & $C \mathrm{~T}$ & T & 1 & 1 & $T$ & T & C & T & T & T & $\mathrm{T}$ & $\mathrm{T}$ & $\mathrm{T}$ & $\begin{array}{ll}- & \text { r }\end{array}$ & - & - & - & - & - & & A & $\begin{array}{ll}T & T\end{array}$ & $T$ & A & $T$ & $T$ & $\mathrm{~T}$ & & G & & A & $\mathrm{T}$ & 1 \\
\hline 24. $\mathrm{ct}$ & 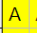 & A & C & A & C & T & A $A$ & A & T & $\mathrm{T}$ & T T & $\mathrm{T} C$ & C $\mathrm{T}$ & T & $\mathrm{T}$ & T & T & T & T & $\mathrm{T}$ & T & $\mathrm{T}$ & $\mathrm{T}$ & $\mathrm{T}$ & $\mathrm{T}$ & $\mathrm{T}$ & T & T & T & - & -1 & T $A$ & A & $\begin{array}{ll}T & T\end{array}$ & $T$ & A & $\mathrm{T}$ & $T$ & $\mathrm{~T}$ & A & G A & & A & 1 & \\
\hline 5. ct & A & A & C & A & C & T & A $A$ & A & $\begin{array}{l}\mathrm{T} T \\
\end{array}$ & T & T T & $\mathrm{T} C$ & C $\mathrm{T}$ & $\mathrm{T}$ & $\mathrm{T}$ & $\mathrm{T}$ & T & T & $\mathrm{T}$ & $\mathrm{T}$ & T & T & $\mathrm{T}$ & $\mathrm{T}$ & $\mathrm{T}$ & $\mathrm{T}$ & $\mathrm{T}$ & $\mathrm{T}$ & T & T & T & $\mathrm{T} A$ & A & $\begin{array}{ll}T & T \\
\end{array}$ & $T$ & A & $\mathrm{T}$ & $T$ & $\mathrm{~T}$ & & & & $A$ & $\mathrm{~T}$ & 1 \\
\hline v. CS & A & A & C & A & C & T & A & A & 1 & T & T T & \begin{tabular}{l|l}
$\mathrm{T}$ & $\mathrm{T}$
\end{tabular} & $\begin{array}{l}T \\
T\end{array}$ & - & - & - & - & - & - & - & - & - & - & 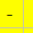 & 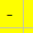 & 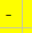 & - & - & - & - & - & A & A & $\begin{array}{ll}T & T\end{array}$ & $\mathrm{~T}$ & A & $\mathrm{T}$ & $\mathrm{T}$ & $\mathrm{T}$ & & G & & $A$ & $\mathrm{~T}$ & $T$ \\
\hline v7. wt & A & A & C & A & C & T & A & A & C T & $T$ & T A & $\begin{array}{ll}A \\
A\end{array}$ & $\begin{array}{l}T \\
T\end{array}$ & $\begin{array}{ll}- & - \\
\end{array}$ & $\begin{array}{lll}- & - \\
\end{array}$ & - & - & $\begin{array}{ll}- \\
-\end{array}$ & - & - & $\begin{array}{ll}- \\
-\end{array}$ & - & - & - & - & - & $\begin{array}{ll}- \\
-\end{array}$ & - & - & - & - & A & A T & $\begin{array}{ll}T & T \\
\end{array}$ & $T$ & A & $T$ & $T$ & $\mathrm{~T}$ & & A A & & $A$ & C & T \\
\hline 8. w & A & A & C & A & T & T & A & A & $T$ & T & T A & $T$ & T & 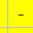 & - & - & - & - & - & - & - & - & - & - & - & - & - & - & - & - & 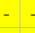 & A & A $T$ & $\begin{array}{ll}T & T \\
\end{array}$ & $\mathrm{~T}$ & A & $\mathrm{T}$ & $\mathrm{T}$ & $\mathrm{T}$ & A & A & & $A$ & C & \\
\hline -9. wt/ & A & A & C & A & C & T & A & A & C T & T & T A & $\begin{array}{l}A T \\
\end{array}$ & $\begin{array}{l}T \\
T\end{array}$ & - & - & - & - & - & - & - & - & - & - & - & - & - & - & - & - & - & - & $-A$ & $\begin{array}{l}A T \\
\end{array}$ & $\begin{array}{ll}T & T \\
\end{array}$ & $\mathrm{~T}$ & A & $\mathrm{T}$ & $T$ & $\mathrm{~T}$ & & A A & & $A$ & C & T \\
\hline 10. & A & A & C & A & C & T & A & A & $C$ & $\mathrm{~T}$ & T A & $\begin{array}{ll}A & T\end{array}$ & $\begin{array}{ll}T & T \\
\end{array}$ & - & - & - & - & - & - & - & - & - & 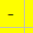 & 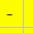 & - & - & - & - & - & - & - & & A & $\begin{array}{ll}T & T \\
\end{array}$ & $\mathrm{~T}$ & G & $\mathrm{T}$ & $\mathrm{T}$ & $\mathrm{T}$ & A & A & & $A$ & $\mathrm{~T}$ & \\
\hline$\nabla 11 . w$ & A & A & C & A & $\mathrm{T}$ & T & A & A & C T & $\mathrm{T}$ & T A & $A$ & $\begin{array}{ll}T & T \\
\end{array}$ & - & - & - & - & - & - & - & - & - & - & - & - & - & - & - & - & - & - & & $\begin{array}{l}A T \\
\end{array}$ & $\begin{array}{ll}T & T \\
\end{array}$ & $\mathrm{~T}$ & A & $\mathrm{T}$ & $\mathrm{T}$ & $\mathrm{T}$ & A & A A & $A T$ & $A$ & C & T \\
\hline 12. & A & A & C & A & $\mathrm{T}$ & T & A & A & C T & $\mathrm{T}$ & T A & $A$ & $\begin{array}{ll}\mathrm{T} & \mathrm{T}\end{array}$ & 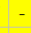 & - & $\begin{array}{ll}- \\
-\end{array}$ & - & - & $\begin{array}{lll}- & - \\
\end{array}$ & - & 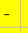 & $\begin{array}{ll}- \\
-\end{array}$ & - & - & - & - & $\begin{array}{ll}- \\
-\end{array}$ & - & $\begin{array}{lll}- & -\end{array}$ & $\begin{array}{ll}- & - \\
\end{array}$ & - & & $\begin{array}{l}A T \\
\end{array}$ & $\begin{array}{ll}T & T\end{array}$ & $\mathrm{~T}$ & A & 1 & 1 & $\mathrm{~T}$ & & A A & & $A$ & C & 1 \\
\hline$\nabla 13$. & A & A & C & A & $\mathrm{T}$ & T & A & A & C T & $\mathrm{T}$ & T A & A 1 & $\begin{array}{ll}T & T\end{array}$ & - & - & - & - & - & - & - & - & - & - & - & - & - & - & - & - & $\begin{array}{lll}- & - \\
\end{array}$ & - & & A & $\begin{array}{ll}T & T\end{array}$ & $\mathrm{~T}$ & A & $\mathrm{T}$ & $\mathrm{T}$ & $\mathrm{T}$ & A & A & $A T$ & $A$ & C & 1 \\
\hline च14. w & A & A & C & A & C & T & A & A & C 1 & T & T & T & $\begin{array}{l}T \\
T\end{array}$ & - & - & - & - & - & - & - & - & - & - & - & - & - & $\begin{array}{ll}- & \text { r }\end{array}$ & - & - & - & - & & $A C$ & $\begin{array}{c}C \mathrm{~T} \\
\mathrm{C}\end{array}$ & T & A & $\mathrm{T}$ & $\mathrm{T}$ & $\mathrm{T}$ & A & A A & & A & C & T \\
\hline -15.v & A & A & C & A & T & T & A & A & C & T & T A & A 1 & $\begin{array}{l}T \\
T\end{array}$ & - & - & - & - & - & - & - & - & - & - & - & - & - & - & - & - & - & - & & $A T$ & $\begin{array}{c}T \\
T\end{array}$ & T & A & $\mathrm{T}$ & $\mathrm{T}$ & $\mathrm{T}$ & & A A & & A & C & 1 \\
\hline$\nabla 16 . w$ & A & A & C & A & $T$ & T & A & A & C & $\mathrm{T}$ & $\mathrm{T} A$ & A & $\begin{array}{ll}T & T\end{array}$ & $\begin{array}{lll}- & \text { r }\end{array}$ & - & - & - & $\begin{array}{ll}- \\
-\end{array}$ & $\begin{array}{l}- \\
-\end{array}$ & - & $\begin{array}{ll}- \\
-\end{array}$ & - & - & $\begin{array}{ll}- \\
-\end{array}$ & $\begin{array}{lll}- & - \\
\end{array}$ & $\begin{array}{ll}- \\
-\end{array}$ & - & - & $\begin{array}{ll}- & - \\
-1\end{array}$ & - & $\begin{array}{ll}- & \text { r }\end{array}$ & & $\begin{array}{l}A T \\
\end{array}$ & $\begin{array}{ll}T & T\end{array}$ & $\mathrm{~T}$ & A & $\mathrm{T}$ & $\mathrm{T}$ & $\mathrm{T}$ & A $A$ & A A & $\begin{array}{l}A T \\
\end{array}$ & $A$ & C & T \\
\hline 17. & A & A & C & A & $\mathrm{T}$ & T & A & A & C & $T$ & T A & A & $\begin{array}{ll}T & T\end{array}$ & - & - & - & - & - & - & - & - & - & - & - & - & - & $\begin{array}{ll}- \\
-\end{array}$ & - & $\begin{array}{ll}- \\
-\end{array}$ & - & - & A & $\begin{array}{l}A T \\
\end{array}$ & $\begin{array}{ll}T & T\end{array}$ & T & A & $T$ & $\mathrm{~T}$ & $\mathrm{~T}$ & & A A & & $A$ & C & 1 \\
\hline JN-2011 & A & A & C & A & C & T & & A & T & $\mathrm{T}$ & T & $\begin{array}{l}\mathrm{T} \\
\mathrm{T}\end{array}$ & $\begin{array}{l}T \\
T\end{array}$ & $\begin{array}{ll}- & \text { r }\end{array}$ & - & - & - & - & - & 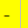 & - & - & - & - & - & - & - & & - & - & - & A & A & $\begin{array}{l}T \\
T\end{array}$ & 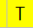 & A & $\mathrm{T}$ & $\mathrm{T}$ & $\mathrm{T}$ & & G G & & A & & \\
\hline
\end{tabular}

Figure 13. Sequence alignment of $\mathrm{C}$-strain vaccine, Shimen strain virus, $4 \mathrm{C}$-strain vaccine positive samples and 12 wild-type virus positive samples. The T-rich insertions were circumscribed by the red lines. Sequence 1:

C-strain vaccine, Sequence 2-5: C-strain vaccine positive samples, Sequence 6: Shimen strain virus, Sequence 7-18: Wild-type virus positive Samples 
CSFV_C-Strain_Z46258

ct_1-60_SDJN-2011 ct_2-8_SDJN-2011

ct_2-33_SDJN-2011

ct_1-3 HNNY-2012

CSFV Shimen AY775178

wt_1-5_HNNY-2011

wt_2-31_HNNY-2011

wt_2-59_HNNY-2011

wt 1-11 HNNY-2012

wt $1-19$ HBZZ - 2011

wt_2-41_HBZZ-2011

wt_2-55_HBZZ-2011

wt_1-21 HBZZ-2012

wt 1-22 HBZZ-2012

wt_1-37_HBZZ-2012

wt_1-9_SDJN-2011

wt_1-12_SDJN-2011

CSFV_C-Strain_Z46258

ct_1-60_SDJN- 2011

ct_2-8_SDJN-2011

ct_2-33_SDJN-2011

ct_1-3_HNNY-2012

CSFV_Shimen_AY775178

wt_1-5_HNNY-2011

$w t+2-3 \overline{1}+H N N Y-2011$

wt $2-59$ HNNY -2011

wt_1-11_HNNY-2012

wt_1-19_HBZZ-2011

wt_2-41_HBZZ-2011

wt 2-55 HBZZ-2011

wt $1-21$ HBZZ-2012

wt_1-22_HBZZ-2012

wt_1-37_HBZZ-2012

wt $1-9$ SDJN-2011

wt_1-12_SDJN-2011

CSFV_C-Strain_Z46258

ct $1-60$ SDJN-2011

ct_2-8_SDJN-2011

ct_2-33_SDJN-2011

ct_1-3_HNNY-2012

CSFV_Shimen_AY775178

wt_1-5_HNNY-2011

wt_2-31_HNNY-2011

wt_2-59_HNNY-2011

wt 1-11 HNNY - 2012

wt 1-19 HBZZ-2011

wt_2-41_HBZZ-2011

wt_2-55_HBZZ-2011

wt_1-21_HBZZ-2012

wt_1-22 HBZZ-2012

wt_1-37_HBZZ-2012

wt_1-9_SDJN-2011

wt_1-12_SDJN-2011

CSFV_C-Strain_Z46258

ct $1-60$ SDJN-2011

ct 2-8 SDJN-2011

ct_2-33_SDJN-2011

ct_1-3_HNNY-2012

CSFV Shimen AY775178

wt 1-5 HNNY-2011

wt $2-3 \overline{1}$ HNNY -2011

wt_2-59_HNNY-2011

wt_1-11_HNNY-2012

wt $1-19$ HBZZ-2011

wt 2-41 HBZZ-2011

wt_2-55_HBZZ-2011

wt_1-21_HBZZ-2012

wt_1-22-HBZZ-2012

wt $1-37$ HBZZ -2012

wt $1-9$ SDJN-2011

wt_1-12_SDJN-2011
ATGATGATGGCGCTGATAGGGAGAGGGGCATGAGCGCGGGTAACCCGGGATCTGAAC

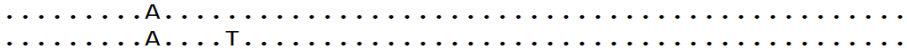

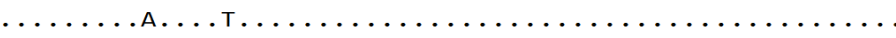

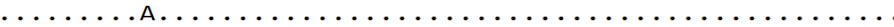

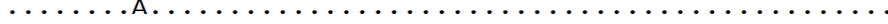

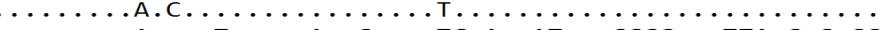

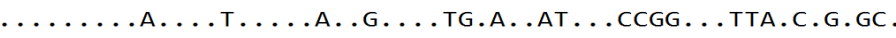

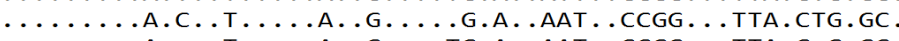
........... .....A..G...TG.A. .AAT..CCGG...TTA.C.G.GC. $\ldots \ldots . . . .$. ............TG.A...AT . CCGG...TTA.C.G.GC $-\ldots .$. A.C..T....A..G..A..G.A. .AAT .CCGG.. TTA.CTG.GC. .......... . . ...... . . TG.A. . AAT . CAGG . . TTA. CTG.GC

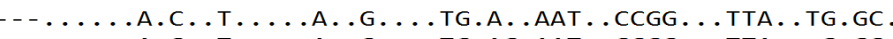
........... . ....A..G...TG.AG.AAT . CCGG ..TTA...G.GC

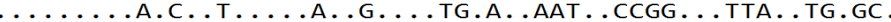
$\ldots \ldots$..... . .........TG.A. .AAT . CAGG . . TTA.CTG.GC

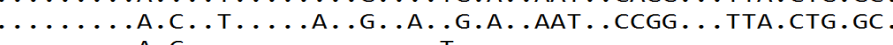

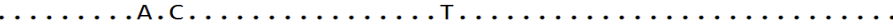

CCGCCAGTAGGACCCTATTGTAGATAACACTAATTTTCTTTTTTTTTTTTTTTTTTT

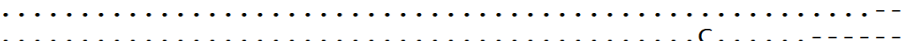

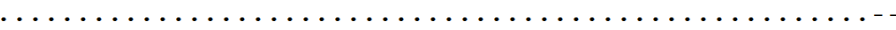
$\ldots \ldots \ldots \ldots \ldots$ ТАТ. . . TAT...G.A....G.........T.....AT

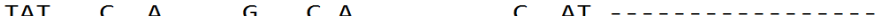

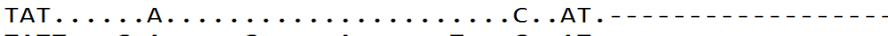

TATT...G.A...G................AT .

.ТАТ................... . . . .АТ

TAT .................. .....AT

.

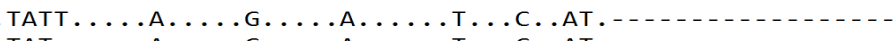

ТАT ................... . . . . .АT

TATT...G.A...G....A..........AT

(1.

TATTTATTTAgATATTATTATTTATTTATTTATTTATTTATTGAATGAgTAAgAACT

.

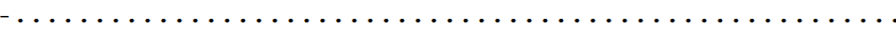

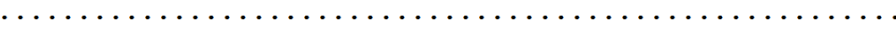

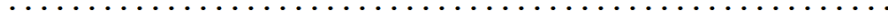

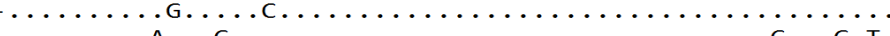

$-\ldots \ldots \ldots$ A. . . . . . . . . . . .

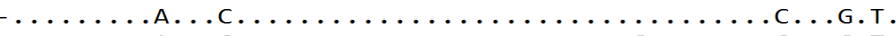

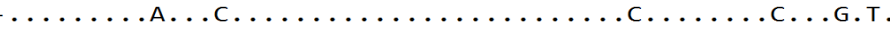

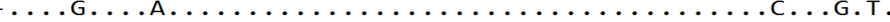

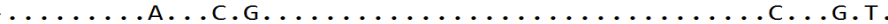

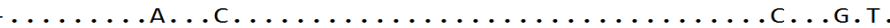

....... . . . . . . . . .

- . ............................

....................... T

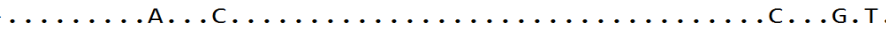

........ . . . . . . . .

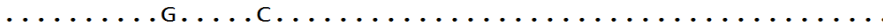

GGTATAAACTACCTCAAGTTACCACAC

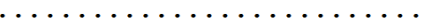

$\ldots \ldots \ldots \ldots \ldots \ldots \ldots \ldots$

$\ldots \ldots \ldots \ldots \ldots \ldots \ldots$

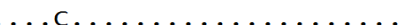

${ }_{1}$

......... Т.....

$\ldots$.............

$\ldots \subset \ldots \ldots \ldots \ldots \ldots$

$\ldots \subset \ldots \ldots \ldots \ldots \ldots$

.......... . . . . .

$\ldots \subset \ldots \ldots \ldots \ldots$.........

$\ldots c \ldots \ldots \ldots \ldots \ldots \ldots$

$\ldots \subset \ldots \ldots$........

$\ldots \subset \ldots \ldots \ldots \ldots \ldots \ldots$

$\ldots \subset \ldots \ldots \ldots \ldots \ldots \ldots$

$\ldots \ldots \ldots \ldots \ldots \ldots \ldots$

Figure 14. Complete sequence alignment of the nested PCR fragments of C-strain vaccine, Shimen strain virus, 4 $\mathrm{C}$-strain vaccine positive samples and 12 wild-type virus positive samples

\section{Discussion}

A lapinized hog cholera vaccine, now well known as "C-strain" was developed by a group of scientists of China Institute of Veterinary Drug Control in the middle 1950's. This vaccine was generated by passing the highly virulent parent Shimen strain in rabbits for several hundred passages. There exist several versions of C-strain for 
vaccine production and basic research, but in most cases, C-strain refers to the Chinese lapinized hog cholera vaccine (Qiu, 2006). The C-strain vaccine has been put into massive use in mainland China for nearly 60 years, demonstrated desirable safety, efficacy and stability. Numerous evidences have proven this vaccine is of high efficacy, providing immunized animals with broad-spectrum, sometimes lifelong, protection, which is contributed by both cell-mediated immunity and humoral immunity of vaccinated pigs, effectively against all genotypes or subgenotypes of the viruses (Qiu, 2006). However, the vaccine viruses can persist in pigs for a relatively long period of time after vaccination (Lorena et al., 2001). Data from National Classical Swine Fever Reference Laboratory (China) indicated that the C-strain vaccine can still be detected in pig tonsils 42 days after vaccination using a real time RT-PCR assay and RT-nestPCR assay established in this study (not shown, unpublished). This phenomenon can greatly interfere with the detection of CSFV wild-type virus infection. Therefore, the development of a reliable and accurate differential diagnostic tool for C-strain vaccine and wild-type virus is of significant importance.

The RT-nestPCR assay developed in this study can distinguish CSFV C-strain vaccine from wild-type viruses accurately and rapidly. The primer pairs were designed on the conservative regions of NS5B and 3'-UTR regions of CSFV genomes after sequence comparison and alignment. The nested PCR products were analyzed by electrophoresis through $4 \%(\mathrm{w} / \mathrm{v})$ super fine resolution (SFR) agarose gel and the C-strain vaccine and the wild-type virus can be accurately distinguished. The detection limit of RT-nestPCR assay to CSFV C-strain vaccine and Shimen strain virus were $4.5 \times 10^{-2} \mathrm{pg}$ and $3.2 \times 10^{-2} \mathrm{pg}$ of viral RNA respectively. The assay is of high sensitivity and can detect early stage infection. In current study, 4 clinical samples were C-strain vaccine positive and 12 clinical samples were wild-type virus positive detected by the RT-nestPCR assay among 400 tonsil tissue samples. All the nested PCR products of 16 positive samples were cloned into vectors after purification and sequenced. The results demonstrated that the T-rich insertion regions were found in the sequences of $4 \mathrm{C}$-strain vaccine positive samples, and the sequences of 12 wild-type virus positive samples were free of the T-rich insertion which further approved the accuracy of differential detection of the RT-nestPCR assay.

The results of the sequencing of the nested PCR products also demonstrated that the length of T-rich insertion is not universally of 12nt which are shown both in Figures 13 and 14, the lengths of the T-rich insertions of the 4 CSFV C-strain vaccines detected from the clinical samples are not the same, some are longer than $12 \mathrm{nt}$. This phenomenon has been previously reported (Fan, 2011), and the same phenomenon also existed on the CSFV Thiverval strain vaccine. The length of T-rich insertion is of distinct heterogeneity in the same strain. RNA viruses will generate a diverse mutant repertoire within several generations for they replicate at a high mutation rate and a complex mutant distributions termed as viral quasispecies can be formed (Woo \& Reifman, 2012). According to population genetics, the frequency of a given variant in a population is mainly determined by its fitness reflected by its ability of survival and proliferation (Lauring \& Andino, 2010). Among the tested vaccines, 7 batches were produced in rabbits and 7 batches were produced by cell culture. As shown by Figure 12, the nested PCR products of Lane 3, Lane 6-10, Lane 16 belong to the vaccines produced in rabbits and the nested PCR products of Lane 4-5, Lane 11-15 belong to the vaccines produced by cell culture. The sizes of nested PCR products of the 14 batches of $\mathrm{C}$-strain vaccines are not identical, slight differences can be observed. In Figure 12, the nested PCR products of Lane 3, Lane 6-10, Lane 16 are relatively smaller than that of Lane 4-5, Lane 11-15. The results indicated that the length of T-rich insertion of $\mathrm{C}$-strain vaccines produced in rabbits maybe shorter than that of C-strain vaccines produced by cell culture. It is known that the virus titer of vaccines produced in rabbits is much lower than that of vaccines produced by cell culture which may indicate that $\mathrm{C}$-strain vaccines produced by cell culture are more adaptable to propagate on cell lines. Therefore, it can be speculated that in the case of CSFV C-strain vaccine culture, the T-rich insertion was formed at a certain point of the passages of the vaccine strain to meet the need of fitness, and the relatively long T-rich insertion seems to be able to increase the adaptability to cell culture of the vaccine virus which is indicated by the titer of virus.

Different Taqman real time RT-PCR assays have been reported to detect C-strain vaccines or/and wild-type viruses (Cheng et al., 2008; Depner et al., 2007; Eberling et al., 2011; Hoffmann et al., 2011; Pérez et al., 2011). The Taqman probes were designed based on the mutations of single or multiple positions of the target nucleotide sequences and can detect single nucleotide polymorphism (SNP). Recently, a triplex TaqMan real time RT-PCR assay for detection of different strains of CSFV has been reported (Zhang et al., 2012). Real time PCR assay is of high sensitivity, high throughout. However, the false positive occurred in the practical application of real time PCR is inevitable (Risatti et al., 2005). More importantly, TaqMan probe is extremely specific to target sequence, especially the TaqMaq MGB probe; one single mismatch will make the probe unable to hybridize with its complementary target. The genomes of CSFV wild-type viruses have a high mutation rate on certain positions due to host immune selection pressure and high error rate of RNA dependent RNA polymerase. Therefore, a 
single TaqMan probe is unable to include all strains and isolates of CSFV wild-type viruses. The detection scope of real time PCR is then limited. In current study, degenerate bases were added in the primers to increase the detection scope in amplifying different strains and isolates of CSFV while without amplifying other non-CSFV viruses, especially the closely related pestiviruses. Degenerate bases are a group of bases that have the unique ability to substitute any of the four normal bases (A, G, T, and C) without substantially interfering the interactions of the neighboring base-pairs or disrupting the expected function of the modified oligonucleotides. Degenerate bases can be added into the Oligonucleotides and function as common PCR primers. For instance, the purine (A or $\mathrm{G}$ ) analogue $\mathrm{N}^{6}$-methoxy-2, 6-diaminopurine can pair with $\mathrm{T}$ or $\mathrm{C}$ instead of just one. Therefore, compared to real time RT-PCR, the RT-nestPCR assay established in this study has a broader detection scope.

In the detection of 400 clinical samples, 12 samples were detected positive for CSFV wild-type viruses and 4 samples were detected positive for CSFV C-strain vaccine, the total positive rate is $4 \%$. CSFV positive rate in clinical healthy pigs in GuanXi province of Southern China has been reported before, it's about 3\% (Luo et al., 2011). The results indicated that $C$-strain vaccine can exist in pigs for a long period of time after vaccination, and persistently infected clinically healthy pigs exist in different breeding swine farms. The existence of persistently infected pigs is a major impediment in eradication of CSFV.

The RT-nestPCR assay established in this study is of broad detection scope, high sensitivity and high specificity. It can provide a rapid diagnostic tool for differential detection of pigs infected with wild-type viruses and those vaccinated with $\mathrm{C}$-strain vaccines in the field. It can also provide a sensitive tool for purity test of $\mathrm{C}$-strain vaccine manufacturing.

\section{Acknowledgements}

This study was conducted under the support of Special Fund for Agro-scientific Research in the Public Interest (200903055, 200803020).

\section{References}

Altschul, S. F., Gish, W., Miller, W., Myers, E. W., \& Lipman, D. J. (1990). Basic local alignment search tool. J. Mol. Biol., 215, 403-410. http://dx.doi.org/10.1006/jmbi.1990.9999

Canal, C. W., Hotzel, I., de Almeida, L. L., Roehe, P. M., \& Masuda, A. (1996). Differentiation of classical swine fever virus from ruminant pestiviruses by reverse transcription and polymerase chain reaction (RT-PCR). Vet Microbiol, 48, 373-379. http://dx.doi.org/10.1016/0378-1135(95)00156-5

Cheng, D., Zhao, J. J., Li, N., Sun, Y., Zhou, Y. J., Zhu, Y., Tian, Z. J., ... Qiu, H. J. (2008). Simultaneous detection of Classical swine fever virus and North American genotype Porcine reproductive and respiratory syndrome virus using a duplex real-time RT-PCR. J Virol Methods, 151, 194-199. http://dx.doi.org/10.1016/j.jviromet.2008.05.011

Depner, K., Hoffmann, B., \& Beer, M. (2007). Evaluation of real-time RT-PCR assay for the routine intra vitam diagnosis of classical swine fever. Veterinary Microbiology, 121, 338-343. http://dx.doi.org/10.1016/j.vetmic.2006.12.027

Depner, K., Paton, D. J., Cruciere, C., De Mia, G. M., Muller, A., Koenen, F., ... Liess, B. (1995). Evaluation of the enzyme-linked immunosorbent assay for the rapid screening and detection of classical swine fever virus antigens in the blood of pigs. Rev Sci Tech, 14, 677-689.

Dewulf, J., Koenen, F., Mintiens, K., Denis, P., Ribbens, S., \& de Kruif, A. (2004). Analytical performance of several classical swine fever laboratory diagnostic techniques on live animals for detection of infection. $J$ Virol Methods, 119, 137-143. http://dx.doi.org/10.1016/j.jviromet.2004.03.010

Eberling, A. J., Bieker-Stefanelli, J., Reising, M. M., Siev, D., Martin, B. M., McIntosh, M. T., \& Beckham, T. R. (2011). Development, optimization, and validation of a Classical swine fever virus real-time reverse transcription polymerase chain reaction assay. $J$ Vet Diagn Invest, 23, 994-998. http://dx.doi.org/10.1177/1040638711416970

FanYun-feng, Z. Q. Z., Zhao, Y.,, Zou, X. Q., Zhang, Z. Q., Wang, Q., \& Ning, Y. B. (2011). Heterogeneity and Secondary Structure Analysis of 3' Untranslated Region in Classical Swine Fever Viruses. Agricultural Sciences in China, 142-148.

Fauquet, C. M., \& Mayo, M. A. (2001). The 7th ICTV report. Arch Virol, 146, 189-194. http://dx.doi.org/10.1007/s007050170203

Greiser-Wilke, I., Dreier, S., Haas, L., \& Zimmermann, B. (2006). Genetic typing of classical swine fever 
viruses--a review. DTW. Deutsche tierarztliche Wochenschrift, 113, 134-138.

Haegeman, A., Dewulf, J., Vrancken, R., Tignon, M., Ribbens, S., \& Koenen, F. (2006). Characterisation of the discrepancy between PCR and virus isolation in relation to classical swine fever virus detection. J. Virol Methods, 136, 44-50. http://dx.doi.org/10.1016/j.jviromet.2006.03.028

Handel, K., Kehler, H., Hills, K., \& Pasick, J. (2004). Comparison of Reverse Transcriptase-Polymerase Chain Reaction, Virus Isolation, and Immunoperoxidase Assays for Detecting Pigs Infected with Low, Moderate, and High Virulent Strains of Classical Swine Fever Virus. Journal of Veterinary Diagnostic Investigation, 16, 132-138. http://dx.doi.org/10.1177/104063870401600207

Hoffmann, B., Beer, M., Reid, S. M., Mertens, P., Oura, C. A., van Rijn, P. A., ... King, D. P. (2009). A review of RT-PCR technologies used in veterinary virology and disease control: sensitive and specific diagnosis of five livestock diseases notifiable to the World Organisation for Animal Health. Vet Microbiol, 139, 1-23. http://dx.doi.org/10.1016/j.vetmic.2009.04.034

Hoffmann, B., Blome, S., Bonilauri, P., Fernandez-Pinero, J., Greiser-Wilke, I., Haegeman, A., ... Beer, M. (2011). Classical swine fever virus detection: results of a real-time reverse transcription polymerase chain reaction ring trial conducted in the framework of the European network of excellence for epizootic disease diagnosis and control. Journal of Veterinary Diagnostic Investigation, 23, 999-1004. http://dx.doi.org/10.1177/1040638711416849

Lauring, A. S., \& Andino, R. (2010). Quasispecies theory and the behavior of RNA viruses. PLoS Pathog, 6, e1001005. http://dx.doi.org/10.1371/journal.ppat.1001005

Li, Y., Zhao, J.J., Li, N., Shi, Z., Cheng, D., Zhu, Q. H., ... Qiu, H. J. (2007). A multiplex nested RT-PCR for the detection and differentiation of wild-type viruses from C-strain vaccine of classical swine fever virus. Journal of Virological Methods, 143, 16-22. http://dx.doi.org/10.1016/j.jviromet.2007.01.032

Liu, L., Widén, F., Baule, C., \& Belák, S. (2007). A one-step, gel-based RT-PCR assay with comparable performance to real-time RT-PCR for detection of classical swine fever virus. Journal of Virological Methods, 139, 203-207. http://dx.doi.org/10.1016/j.jviromet.2006.10.007

Lorena, J., Barlic-Maganja, D., Lojkic, M., Madic, J., Grom, J., Cac, Z., ... Cajavec, S. (2001). Classical swine fever virus (C strain) distribution in organ samples of inoculated piglets. Vet Microbiol, 81, 1-8. http://dx.doi.org/10.1016/S0378-1135(01)00321-2

Luo, T. R., Liao, S. H., Wu, X. S., Feng, L., Yuan, Z. X., Li, H., ... Zhang, H. Y. (2011). Phylogenetic analysis of the E2 gene of classical swine fever virus from the Guangxi Province of southern China. Virus Genes, 42, 347-354. http://dx.doi.org/10.1007/s11262-011-0578-8

Mayo, M. A., \& Haenni, A. L. (2006). Report from the 36th and the 37th meetings of the Executive Committee of the International Committee on Taxonomy of Viruses. Arch Virol, 151, 1031-1037. http://dx.doi.org/10.1007/s00705-006-0728-9

Moennig, V. (2000). Introduction to classical swine fever: virus, disease and control policy. Vet Microbiol, 73, 93-102. http://dx.doi.org/10.1016/S0378-1135(00)00137-1

Moormann, R. J., van Gennip, H. G., Miedema, G. K., Hulst, M. M., \& van Rijn, P. A. (1996). Infectious RNA transcribed from an engineered full-length cDNA template of the genome of a pestivirus. J. Virol., 70, 763-770.

Nie, Y., Ke, Y., Chen, J., \& Ding, M. (2001). Construction of the full-length cDNA clone of Chinese virulent strain-F114. Acta microbiologica Sinica, 41, 452-456.

Ophuis, R. J. A. O., Morrissy, C. J., Boyle, D. B. (2006). Detection and quantitative pathogenesis study of classical swine fever virus using a real time RT-PCR assay. Journal of Virological Methods, 131, 78-85. http://dx.doi.org/10.1016/j.jviromet.2005.07.008

Pérez, L. J., Díaz de Arce, H., Tarradas, J., Rosell, R., Perera, C. L., Muñoz, M., ... Ganges, L. (2011). Development and validation of a novel SYBR Green real-time RT-PCR assay for the detection of classical swine fever virus evaluated on different real-time PCR platforms. Journal of Virological Methods, 174, 53-59. http://dx.doi.org/10.1016/j.jviromet.2011.03.022

Qiu, H. J., Shen, R. X.,\& Tong, G. Z. (2006). The Lapinized Chinese Strain Vaccine Against Classical Swine Fever Virus:A Retrospective Review Spanning Half A Century. Agricultural Sciences in China, 5(1), 1-14. http://dx.doi.org/10.1016/S1671-2927(06)60013-8 
Risatti, G., Holinka, L., Lu, Z., Kutish, G., Callahan, J. D., Nelson, W. M., ... Borca, M. V. (2005). Diagnostic Evaluation of a Real-Time Reverse Transcriptase PCR Assay for Detection of Classical Swine Fever Virus. Journal of Clinical Microbiology, 43, 468-471. http://dx.doi.org/10.1128/JCM.43.1.468-471.2005

Sun, Y., Li, H. Y., Tian, D. Y., Han, Q. Y., Zhang, X., Li, N., \& Qiu, H. J. (2011a). A novel alphavirus replicon-vectored vaccine delivered by adenovirus induces sterile immunity against classical swine fever. Vaccine, 29, 8364-8372. http://dx.doi.org/10.1016/j.vaccine.2011.08.085

Sun, Y., Li, H. Y., Zhang, X. J., Chang, T. M., He, F., Wang, X. P., ... Qiu, H. J. (2011b). Comparison of the protective efficacy of recombinant adenoviruses against classical swine fever. Immunology letters, 135, 43-49. http://dx.doi.org/10.1016/j.imlet.2010.09.010

Sun, Y., Li, N., Li, H. Y., Li, M., \& Qiu, H. J. (2010a). Enhanced immunity against classical swine fever in pigs induced by prime-boost immunization using an alphavirus replicon-vectored DNA vaccine and a $\begin{array}{lllll}\text { recombinant } & \text { adenovirus. }\end{array}$ http://dx.doi.org/10.1016/j.vetimm.2010.04.005

Sun, Y., Liu, D. F., Wang, Y. F., Liang, B. B., Cheng, D., Li, N., Qi, Q. F., .. Qiu, H. J. (2010b). Generation and efficacy evaluation of a recombinant adenovirus expressing the E2 protein of classical swine fever virus. Res Vet Sci, 88, 77-82. http://dx.doi.org/10.1016/j.rvsc.2009.06.005

Tu, C., Lu, Z., Li, H., Yu, X., Liu, X., Li, Y., Zhang, H., \& Yin, Z. (2001). Phylogenetic comparison of classical swine fever virus in China. Virus Res, 81, 29-37. http://dx.doi.org/10.1016/S0168-1702(01)00366-5

Van Oirschot, J. T. (2003). Vaccinology of classical swine fever: from lab to field. Veterinary Microbiology, 96, 367-384. http://dx.doi.org/10.1016/j.vetmic.2003.09.008

Vilcek, S., \& Belak, S. (1998). Classical swine fever virus: discrimination between vaccine strains and European field viruses by restriction endonuclease cleavage of PCR amplicons. Acta Vet Scand, 39, 395-400.

Vilcek, S., Herring, A. J., Herring, J. A., Nettleton, P. F., Lowings, J. P., \& Paton, D. J. (1994). Pestiviruses isolated from pigs, cattle and sheep can be allocated into at least three genogroups using polymerase chain reaction and restriction endonuclease analysis. Arch Virol, 136, 309-323. http://dx.doi.org/10.1007/BF01321060

Wong, M. L., Peng, B. Y., Liu, J. J., \& Chang, T. J. (2001). Cloning and sequencing of full-length cDNA of classical swine fever virus LPC strain. Virus Genes, 23, 187-192. http://dx.doi.org/10.1023/A:1011856608580

Woo, H. J., \& Reifman, J. (2012). A quantitative quasispecies theory-based model of virus escape mutation under immune selection. Proceedings of the National Academy of Sciences of the United States of America, 109, 12980-12985. http://dx.doi.org/10.1073/pnas.1117201109

Wu, H. X., Wang, J. F., Zhang, C. Y., Fu, L. Z., Pan, Z. S., Wang, N., ... Zhao, W. G. (2001). Attenuated lapinized chinese strain of classical swine fever virus: complete nucleotide sequence and character of 3'-noncoding region. Virus Genes, 23, 69-76. http://dx.doi.org/10.1023/A:1011829313123

Zhang, X. J., Han, Q. Y., Sun, Y., Zhang, X., \& Qiu, H. J. (2012). Development of a triplex TaqMan real-time RT-PCR assay for differential detection of wild-type and HCLV vaccine strains of classical swine fever virus and bovine viral diarrhea virus 1. Res Vet Sci, 92, 512-518. http://dx.doi.org/10.1016/j.rvsc.2011.03.029

Zhao, J. J., Cheng, D., Li, N., Sun, Y., Shi, Z., Zhu, Q. H., ... Qiu, H. J. (2008). Evaluation of a multiplex real-time RT-PCR for quantitative and differential detection of wild-type viruses and C-strain vaccine of Classical swine fever virus. Veterinary Microbiology, 126, 1-10. http://dx.doi.org/10.1016/j.vetmic.2007.04.046

Zhu, Y., Shi, Z., Drew, T. W., Wang, Q., Qiu, H., Guo, H., \& Tu, C. (2009). Antigenic differentiation of classical swine fever viruses in China by monoclonal antibodies. Virus Res, 142, 169-174. http://dx.doi.org/10.1016/j.virusres.2009.02.011 